\title{
On the origin of tropospheric $\mathrm{O}_{3}$ over the Indian Ocean during the winter monsoon: African biomass burning vs. stratosphere-troposphere exchange
}

\author{
A. T. J. de Laat \\ Space Research Organization Netherlands (SRON), The Netherlands \\ Received: 2 May 2002 - Published in Atmos. Chem. Phys. Discuss.: 10 July 2002 \\ Revised: 28 October 2002 - Accepted: 31 October 2002 - Published: 13 November 2002
}

\begin{abstract}
This study investigates the origin of a commonly observed feature in the $\mathrm{O}_{3}$ profiles: mid tropospheric $\mathrm{O}_{3}$ maxima (300-500 hPa) over the tropical Indian Ocean. A comparison and analysis of model simulations, using a 3-D global climate-chemistry model, and measured $\mathrm{O}_{3}$ profiles from the INDOEX campaign is presented. European Centre for Medium-Range Weather Forecast (ECMWF) meteorological analyses have been assimilated into the 3-D model to represent actual meteorology. The model realistically simulates the observed mid-tropospheric $\mathrm{O}_{3}$ maxima. The analysis of the model simulations shows that the major source of the mid-tropospheric $\mathrm{O}_{3}$ maxima is advection of polluted air masses from continental biomass burning areas over Africa, with generally only a small contribution of stratospheric $\mathrm{O}_{3}$. Previous studies hinted at stratosphere-troposphere exchange (STE) along the subtropical jet (STJ) as the primary source of the mid-tropospheric $\mathrm{O}_{3}$ maxima over the Indian Ocean. Analysis of the model simulations shows that the mechanism causing the mid-tropospheric transport of African biomass burning pollution and stratospheric air masses are frontal zones or waves passing along the subtropical jets, causing advection of tropical air masses in the prefrontal (equatorward) zone. Furthermore, the frontal zones or waves also cause STE at the poleward side of the STJ. The model simulations also indicate that the contribution of STE in general is minor compared to advection and in situ tropospheric production of $\mathrm{O}_{3}$ for the mid-tropospheric $\mathrm{O}_{3}$ budget over the Indian Ocean region.
\end{abstract}

\section{Introduction}

The INDian Ocean Experiment (INDOEX) has provided invaluable observations about the chemical composition of the Indian Ocean atmosphere, in particular $\mathrm{O}_{3}$, during the winter

Correspondence to: A. T. J. de Laat (a.t.j.de.laat@sron.nl) monsoon period (typical November-April). The INDOEX measurements show the presence of free-tropospheric layers with enhanced $\mathrm{O}_{3}$ mixing ratios (de Laat et al., 1999; Mandal et al., 1999; Zachariasse et al., 2000; Peshin et al., 2001; Zachariasse et al., 2001). These layers can be found throughout the free troposphere. Generally, a typical $\mathrm{O}_{3}$ profile over the Indian Ocean can be divided into several layers. In the marine boundary layer $\mathrm{O}_{3}$ mixing ratios are low (outside of coastal regions), caused by an $\mathrm{O}_{3}$-destructive environment (Rhoads et al., 1997; Lal et al., 1998; de Laat and Lelieveld, 2000; Lawrence and Lal, 2001). Between the boundary layer and $8 \mathrm{~km} \mathrm{O} \mathrm{O}_{3}$ mixing ratios are higher. Between 8 and 12 to $14 \mathrm{~km}$ is the zone where convective outflow occurs. This layer can be either high or low in $\mathrm{O}_{3}$, depending on the origin of the air masses that were transported by the convection to this altitude. Finally, an upper-tropospheric layer may be found between 12 to $14 \mathrm{~km}$ and the tropopause (typically 17 $\mathrm{km}$ over the tropical Indian Ocean). In this layer $\mathrm{O}_{3}$ mixing ratios are generally high, although on occasion the layer of convective outflow may extend up to the tropopause.

The upper-tropospheric layers with enhanced $\mathrm{O}_{3}$ mixing ratios are also reported by Folkins et al. (1999), in $\mathrm{O}_{3}$ profiles measured at Samoa (14 S, 170 W) in the Pacific Ocean. Based on the $\mathrm{O}_{3}-\theta_{e}$ (equivalent potential temperature) correlation they concluded that air masses below $14 \mathrm{~km}$ altitude generally were of tropospheric origin, whereas above $14 \mathrm{~km}$ the correlation suggested a stratospheric origin. Furthermore, Folkins et al. (1999) used temperature and humidity profiles to show that convection generally cannot reach altitudes above $14 \mathrm{~km}$ over tropical oceans.

Zachariasse et al. (2000) reported similar uppertropospheric layers with enhanced $\mathrm{O}_{3}$ during the First Field Phase (FFP) of INDOEX, which took place during February and March 1998. They used trajectory analysis and potential vorticity fields derived from the European Center for Medium-Range Weather Forecast (ECMWF) to conclude that STE along the northern hemispheric subtropical jet (NH-

(C) European Geosciences Union 2002 


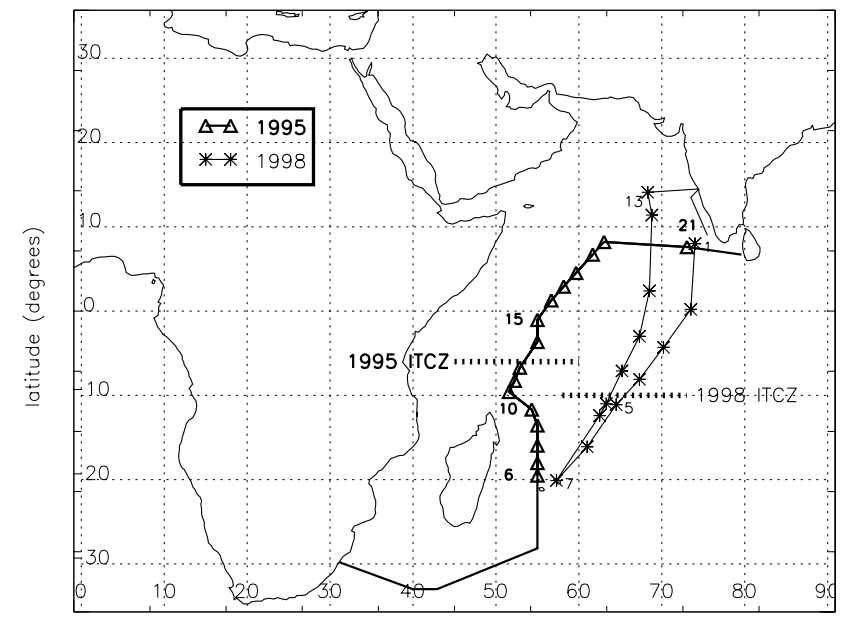

longitude (degrees)

Fig. 1. Ship tracks of the 1995 (R/V Malcolm Baldrige) and 1998 (R/V Sagar Kanya) INDOEX cruises. The locations of the ozone sonde launches as summarized in tables 1 and 2 are also indicated.

STJ) was the major source of the upper-tropospheric $\mathrm{O}_{3}$ laminae, either by shear-induced differential advection or clearair turbulence.

The mid-tropospheric $\mathrm{O}_{3}$ maxima are often associated with (very) low relative humidity (Peshin et al., 2001; Zachariasse et al., 2001). Zachariasse et al. (2001) used this as an indication that the polluted boundary layer over the northern Indian Ocean and India could not be the source of the mid-tropospheric $\mathrm{O}_{3}$ maxima. They also noted that midtropospheric air masses might travel deep into the tropics. de Laat et al. (1999) reported similar mid-tropospheric $\mathrm{O}_{3}$ maxima, observed during March and April 1995. However, these measurements were made closer to Africa (see Fig. 1) and also close to the ITCZ. A 3-D model analysis as well as backtrajectory calculations showed that the major source of these maxima was biomass burning over Africa, with a possible contribution from STE along the southern hemispheric subtropical jet (SH-STJ). Enhanced mid-tropospheric $\mathrm{O}_{3}$ mixing ratios were also observed in $\mathrm{O}_{3}$ profiles measured at Réunion Island during the same period (Baray et al., 1999). Their trajectory and potential vorticity analysis indicated that STE due to the interaction of tropical cyclone Marlene with the SH-STJ could give rise to the $\mathrm{O}_{3}$ maxima they measured. Baray et al. (2001) noted in a comment on de Laat et al. (1999) that some profiles from both de Laat et al. (1999) and Baray et al. (1999) might have the same source regions since they were measured at close locations and at approximately the same time. They questioned whether biomass burning really could be the source because the biomass burning season in Africa south of the equator ends in December. However, in a subsequent reply de Laat and Lelieveld (2001) used 3-D global chemistry-climate model simulations to show that STE was not the source of the $\mathrm{O}_{3}$ maxima. Fur- thermore, they also noted that the modeled $\mathrm{O}_{3}$ maxima were associated with high $\mathrm{CO}$ peaks, another indication that the source of the $\mathrm{O}_{3}$ maxima was tropospheric. In a case study of an extreme pollution event over Réunion Island (Randriambelo et al., 1999) the authors noted there is a need for more thorough model analyses of the chemical and dynamical processes taking place over the southern Indian Ocean region.

More recently, a study by de Laat et al. (2001) investigated the tropospheric source regions of Carbon Monoxide (CO) over the Indian Ocean. Some indications were found of a contribution of African biomass burning to free-tropospheric air masses over the northern Indian Ocean.

\section{Model description}

The general circulation model (GCM) used for this study is the 19-layer European Center HAMburg Model (ECHAM), version 4. Model simulations were performed at T30resolution, approximately $3.75^{\circ} \times 3.75^{\circ}$ with a time resolution of $1800 \mathrm{~s}$. The model uses a hybrid $\sigma-\rho$ vertical coordinate system from the surface to $10 \mathrm{hPa}$. Average pressure levels are 990, 970, 950, 900, 840, 760, 670, 580, 490, $400,320,250,190,140,100,70,50,30$ and $10 \mathrm{hPa}$. Corresponding approximate midlayer altitudes are $0.03,0.14$, $0.38,0.78,1.4,2.1,3.1,4.2,5.6,7.0,8.6,10.2,11.9,13.8$, $15.9,18.0,20.5,23.8$ and $31 \mathrm{~km}$. Tracer transport is calculated using a semi-Lagrangian advection scheme (Rasch and Williamson, 1990). Vertical transport is included through parameterizations of vertical diffusion (Roeckner et al., 1996) and convection (Tiedtke, 1989). A detailed description of ECHAM version 4 is given by Roeckner et al. (1996), Haskins et al. (1995), and Chen and Roeckner (1996).

For this study, I used the standard background chemistry scheme which includes $\mathrm{CH}_{4}-\mathrm{CO}-\mathrm{NO}_{\mathrm{X}}-\mathrm{HO}_{\mathrm{X}}$ chemistry, emissions of $\mathrm{NO}$ and $\mathrm{CO}$, dry deposition of $\mathrm{O}_{3}, \mathrm{NO}_{\mathrm{x}}$, $\mathrm{HNO}_{3}$ and $\mathrm{H}_{2} \mathrm{O}_{2}$, and wet deposition of $\mathrm{HNO}_{3}$ and $\mathrm{H}_{2} \mathrm{O}_{2}$. Concentration changes due to chemical reactions are calculated explicitly for all species by means of an Eulerian Backward Iterative (EBI) scheme (Hertel et al., 1993). A detailed description of the coupled chemistry GCM is given by Roelofs and Lelieveld (1995, 1997).

The model considers a biomass burning source of $6 \mathrm{Tg} \mathrm{N}$

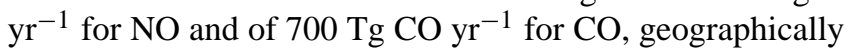
and seasonally distributed according to Hao and Liu (1994). $\mathrm{NO}$ emissions from soils, 5.5 $\mathrm{Tg} \mathrm{N} \mathrm{yr}^{-1}$, are distributed geographically and seasonally according to Yienger and Levy (1995). Lightning $\mathrm{NO}_{\mathrm{X}}$ emissions, $5 \mathrm{Tg} \mathrm{yr}^{-1}$, are distributed according to Price and Rind (1992). The model considers global NO emissions from fossil fuel burning on the order of $21 \mathrm{Tg} \mathrm{N} \mathrm{yr}^{-1}$, according to Benkovitz et al. (1996). CO emissions are distributed according to Lelieveld and van Dorland (1995), consisting of fossil fuel burning (450 $\mathrm{Tg} \mathrm{CO} \mathrm{yr}^{-1}$ ), vegetation (100 $\mathrm{Tg} \mathrm{CO} \mathrm{yr}^{-1}$ ), natural non-methane hydro- 
Table 1. Location and dates of sonde launch during the 1995 INDOEX-cruise with the American R/V Malcolm Baldrige. Sondes were launched around noon local time

\begin{tabular}{cccc}
\hline Sounding & Date & Latitude & Longitude \\
\hline 6 & April 2, 1995 & $19.5^{\circ} \mathrm{S}$ & $55.0^{\circ} \mathrm{E}$ \\
7 & April 4, 1995 & $18.0^{\circ} \mathrm{S}$ & $55.0^{\circ} \mathrm{E}$ \\
8 & April 5, 1995 & $16.0^{\circ} \mathrm{S}$ & $55.0^{\circ} \mathrm{E}$ \\
9 & April 6, 1995 & $13.6^{\circ} \mathrm{S}$ & $55.0^{\circ} \mathrm{E}$ \\
10 & April 7, 1995 & $11.7^{\circ} \mathrm{S}$ & $54.1^{\circ} \mathrm{E}$ \\
11 & April 9, 1995 & $9.6^{\circ} \mathrm{S}$ & $51.9^{\circ} \mathrm{E}$ \\
12 & April 10,1995 & $8.3^{\circ} \mathrm{S}$ & $52.3^{\circ} \mathrm{E}$ \\
13 & April 11, 1995 & $6.7^{\circ} \mathrm{S}$ & $52.9^{\circ} \mathrm{E}$ \\
14 & April 12, 1995 & $3.7^{\circ} \mathrm{S}$ & $55.0^{\circ} \mathrm{E}$ \\
15 & April 13,1995 & $1.0^{\circ} \mathrm{S}$ & $55.0^{\circ} \mathrm{E}$ \\
16 & April 14, 1995 & $1.3^{\circ} \mathrm{N}$ & $56.7^{\circ} \mathrm{E}$ \\
17 & April 15, 1995 & $2.9^{\circ} \mathrm{N}$ & $58.2^{\circ} \mathrm{E}$ \\
18 & April 16, 1995 & $4.5^{\circ} \mathrm{N}$ & $59.7^{\circ} \mathrm{E}$ \\
19 & April 17, 1995 & $6.7^{\circ} \mathrm{N}$ & $61.7^{\circ} \mathrm{E}$ \\
20 & April 18, 1995 & $8.2^{\circ} \mathrm{N}$ & $63.0^{\circ} \mathrm{E}$ \\
21 & April 20,1995 & $7.6^{\circ} \mathrm{N}$ & $73.1^{\circ} \mathrm{E}$ \\
\hline
\end{tabular}

carbon oxidation (280 $\mathrm{Tg} \mathrm{CO} \mathrm{\textrm {yr } ^ { - 1 }}$ ), anthropogenic nonmethane hydrocarbon oxidation (300 $\left.\mathrm{Tg} \mathrm{CO} \mathrm{yr}^{-1}\right)$, oceanic

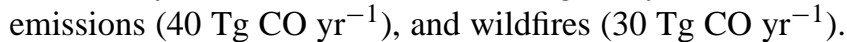
The total $\mathrm{NO}$ and $\mathrm{CO}$ emissions considered in the model

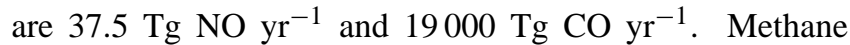
$\left(\mathrm{CH}_{4}\right)$ surface concentrations are prescribed, ranging from $1772 \mathrm{ppm}$ in the northern hemisphere to $1680 \mathrm{ppm}$ in the southern hemisphere.

The parameterization for dry deposition of $\mathrm{O}_{3}, \mathrm{NO}_{\mathrm{X}}$ and $\mathrm{HNO}_{3}$ is described in Ganzeveld and Lelieveld (1995) and Ganzeveld et al. (1998). The wet scavenging of $\mathrm{HNO}_{3}$ and $\mathrm{H}_{2} \mathrm{O}_{2}, \mathrm{CH}_{2} \mathrm{O}, \mathrm{CH}_{3} \mathrm{OOH}$ and $\mathrm{HNO}_{4}$ is calculated using the large-scale and convective cloud and precipitation fields calculated on-line by the climate model as described by Roelofs and Lelieveld (1995, 1997).

The neglect of non-methane hydrocarbons on $\mathrm{O}_{3}$ reduces the net global tropospheric $\mathrm{O}_{3}$ production by $8 \%$ (Roelofs and Lelieveld, 2000). The differences are largest at midlatitudes $(>10 \%)$, smaller in the Indian Ocean free troposphere $(5 \%)$, while becoming negative over the tropical Atlantic ocean (upto $-5 \%$ ).

Stratospheric $\mathrm{O}_{3}$ mixing ratios are prescribed between 1 and 2 model layers above the tropopause up to the $10 \mathrm{hPa}$ top level of the GCM. Transport of $\mathrm{O}_{3}$ across the tropopause depend directly on the air motions simulated by the GCM. The simulated tropopause is marked by a potential vorticity of $3.510^{-6} \mathrm{~K} \mathrm{~m}^{2} \mathrm{~kg}^{-1} \mathrm{~s}^{-2}$ poleward of $20^{\circ}$ latitude (Hoerling et al., 1993), and by a $-2 \mathrm{~K} \mathrm{~km}^{-1}$ temperature lapse rate equatorward of $20^{\circ}$ latitude. Apart from $\mathrm{O}_{3}$, the model considers a tracer for $\mathrm{O}_{3}$ that originates from the stratosphere, referred to as $\mathrm{O}_{3}$ s. The tracer is treated similar to $\mathrm{O}_{3}$, with
Table 2. Location and dates of sonde launch during the First Field Phase (FFP, 1998) INDOEX-cruise with the Indian R/V Sagar Kanya. Sondes were launched in the early afternoon or evening (local time)

\begin{tabular}{cccc}
\hline Sounding & Date & Latitude & Longitude \\
\hline 1 & Feb 23, 1998 & $8.0^{\circ} \mathrm{N}$ & $74.0^{\circ} \mathrm{E}$ \\
2 & March 2, 1998 & $0.2^{\circ} \mathrm{S}$ & $73.5^{\circ} \mathrm{E}$ \\
3 & March 4, 1998 & $4.3^{\circ} \mathrm{S}$ & $70.2^{\circ} \mathrm{E}$ \\
4 & March 6, 1998 & $8.1^{\circ} \mathrm{S}$ & $67.3^{\circ} \mathrm{E}$ \\
5 & March 8, 1998 & $11.1^{\circ} \mathrm{S}$ & $64.5^{\circ} \mathrm{E}$ \\
6 & March 10, 1998 & $16.1^{\circ} \mathrm{S}$ & $61.0^{\circ} \mathrm{E}$ \\
7 & March 13, 1998 & $20.1^{\circ} \mathrm{S}$ & $57.3^{\circ} \mathrm{E}$ \\
8 & March 18, 1998 & $12.4^{\circ} \mathrm{S}$ & $62.5^{\circ} \mathrm{E}$ \\
9 & March 19, 1998 & $11.0^{\circ} \mathrm{S}$ & $63.3^{\circ} \mathrm{E}$ \\
10 & March 20, 1998 & $7.1^{\circ} \mathrm{S}$ & $65.2^{\circ} \mathrm{E}$ \\
11 & March 22, 1998 & $3.0^{\circ} \mathrm{N}$ & $67.3^{\circ} \mathrm{E}$ \\
12 & March 24, 1998 & $2.4^{\circ} \mathrm{N}$ & $68.5^{\circ} \mathrm{E}$ \\
13 & March 27, 1998 & $11.4^{\circ} \mathrm{N}$ & $68.8^{\circ} \mathrm{E}$ \\
14 & March 28, 1998 & $14.1^{\circ} \mathrm{N}$ & $68.3^{\circ} \mathrm{E}$ \\
\hline
\end{tabular}

the exception that no tropospheric production occurs. Thus, in the troposphere $\mathrm{O}_{3} \mathrm{~s}$ is only destroyed (reactions with $\mathrm{OH}$ and $\mathrm{HO}_{2}$, photodissociation and surface deposition).

The model realistically represents the seasonal variability of the $\mathrm{O}_{3}$ photochemical production and of $\mathrm{O}_{3}$ transport from the stratosphere (Roelofs and Lelieveld, 1995, 1997). Surface $\mathrm{O}_{3}$ mixing ratios as measured in remote and relatively clean conditions are also simulated by the model, but the model appears to underestimate the $\mathrm{O}_{3}$ mixing ratios in some polluted regions because of neglect of non-methane hydrocarbon chemistry (Roelofs et al., 1997a; Roelofs and Lelieveld, 2000). The global average crosstropopause $\mathrm{O}_{3}$ flux (CTF) estimates range from $459 \mathrm{Tg} \mathrm{O}$ $\mathrm{yr}^{-1}$ (Roelofs et al., 1997b), $495 \mathrm{Tg} \mathrm{O}_{3} \mathrm{yr}^{-1}$ (Roelofs and Lelieveld, 2000), $575 \mathrm{Tg} \mathrm{O}_{3} \mathrm{yr}^{-1}$ (Roelofs and Lelieveld, 1995), $590 \mathrm{Tg} \mathrm{O}_{3} \mathrm{yr}^{-1}$ (Roelofs and Lelieveld 2000) to 607 $\mathrm{Tg} \mathrm{O}_{3} \mathrm{yr}^{-1}$ (Roelofs and Lelieveld, 2000). The differences are related to different chemistry schemes (with/without non-methane hydrocarbon chemistry; updated photodissociation rates; changes in the description of stratospheretroposphere exchange). In Roelofs and Lelieveld (2000) the estimated range from other GCM model calculations yield cross-tropopause $\mathrm{O}_{3}$ fluxes between 475 and $650 \mathrm{Tg} \mathrm{O}_{3} \mathrm{yr}^{-1}$. Estimates based on correlation between several species $\left(\mathrm{O}_{3}\right.$, $\mathrm{N}_{2} \mathrm{O},{ }^{90} \mathrm{Sr}$, Potential Vorticity) range from 200 to $870 \mathrm{Tg}$ $\mathrm{O}_{3} \mathrm{yr}^{-1}$. At mid-latitudes the model might underestimate the CTF by $10-15 \%$ at the T30 resolution (Siegmund et al., 1996; Kentarchos et al., 2001), however, according to Siegmund et al. (1996) the CTF along the subtropical jets is overestimated (up to 50\%) at the current model resolution.

In this study, the so-called "nudging" technique (for this study the assimilation of ECMWF analysis data) was used 

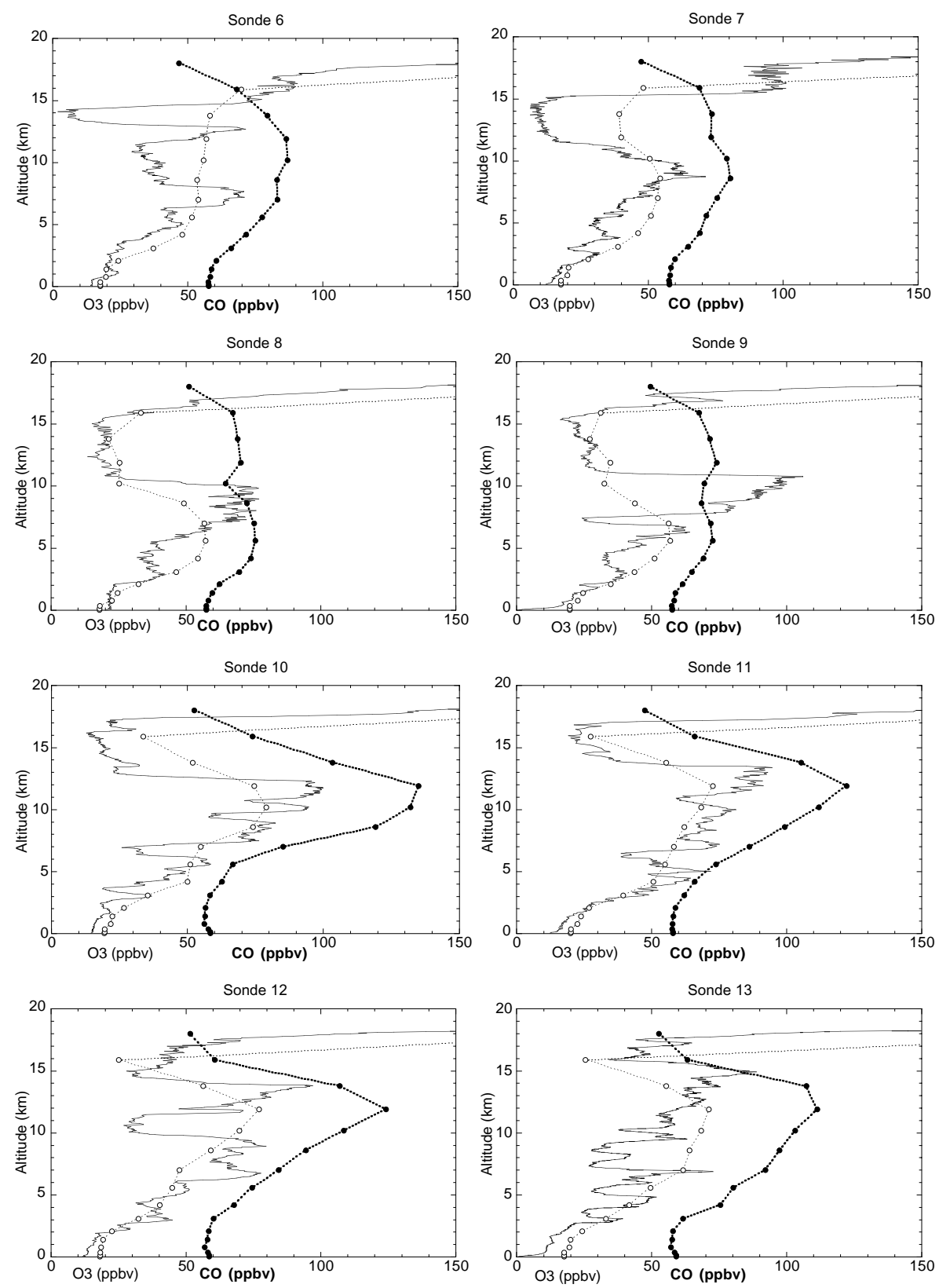

Fig. 2a. Vertical $\mathrm{O}_{3}$ profiles from the 1995 INDOEX cruise profiles No 6 to 13 (solid thin lines), along with the corresponding $\mathrm{O}_{3}$ (dashed thin line, open circles) and $\mathrm{CO}$ (dashed thick lines, filled circles) profiles from the ECHAM model. Mixing ratios are given in ppbv. For the location and launch time see Table 1 .

to simulate specific periods. This method is described more extensively by Jeuken et al. (1996) and de Laat et al. (1999). The periods for which the ECHAM model was nudged in this study were 16 March - 30 April 1995, and 1 February - 1 April 1998. We note that the nudging method has been used for several other studies (Kentarchos et al., 1999, 2000, 2001; de Laat et al., 2001; de Laat and Lelieveld, 2000, 2002).

\section{Observations}

The $\mathrm{O}_{3}$ profiles used in this study were obtained from two pre-INDOEX ship-campaigns. The first campaign took place during March and April of 1995 with the R/V Malcolm Baldrige. From this campaign we used sixteen $\mathrm{O}_{3}$ profiles that were measured along a track from Durban, South Africa to Colombo, Sri Lanka (Fig. 1). Surface measurements of several trace gases, aerosols and meteorological parameters were made along with the soundings. For a detailed description and results of this campaign see Rhoads et al. (1997) and de Laat et al. (1999).

The second campaign took place during February and March 1998 as part of the INDOEX First Field Phase (FFP), a larger preparatory campaign for the INDOEX Intensive Field Phase that would take place during the same months 

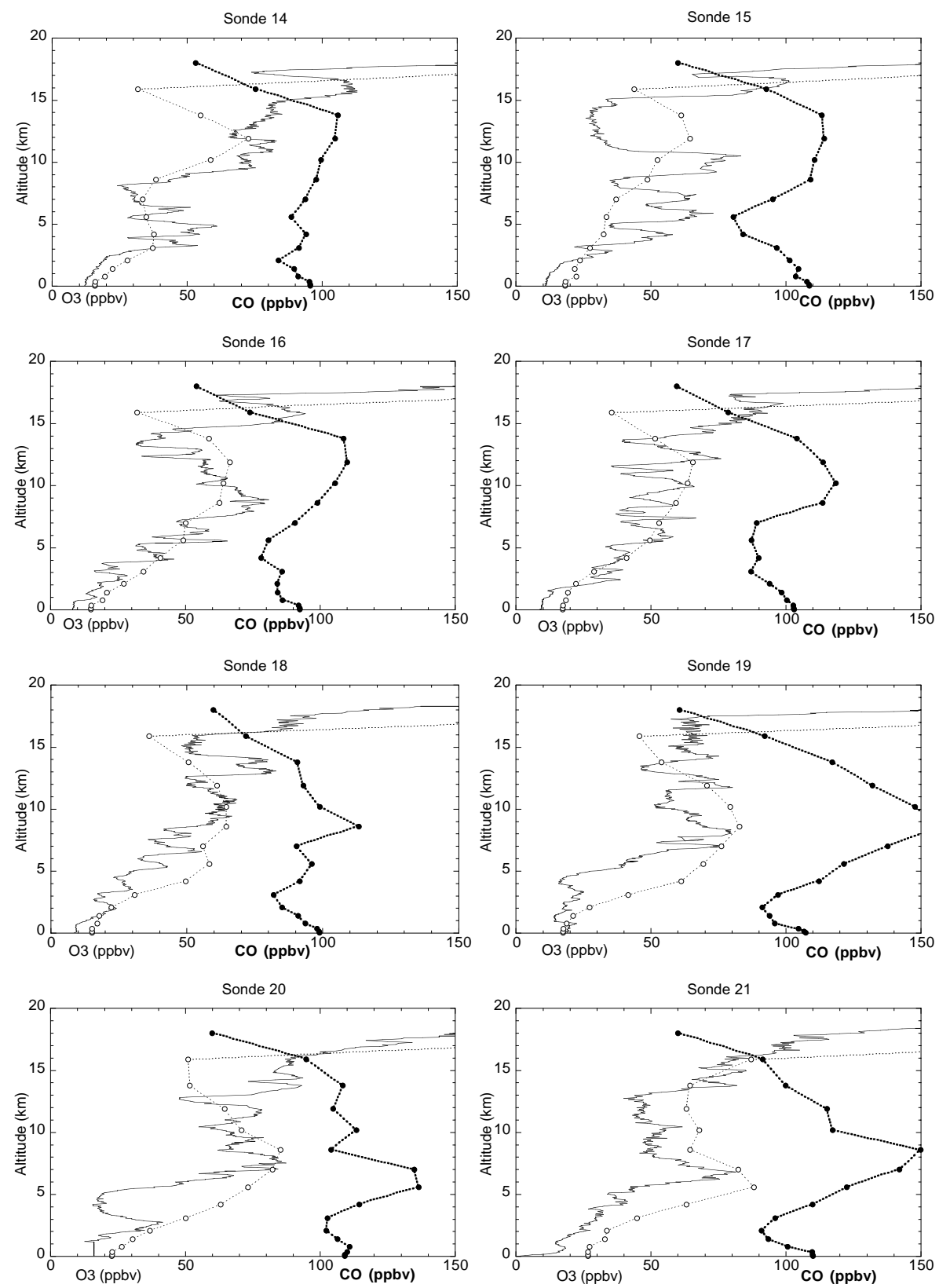

Fig. 2b. Similar to Fig. 2a but for profiles No 14 to 21 .

one year later in 1999. The Indian R/V Sagar Kanya sailed from southern India to the Indian Ocean east of Madagascar (Fig. 2). As in the 1995 campaign, $\mathrm{O}_{3}$ sondes were launched and surface measurements were made.

The $\mathrm{O}_{3}$ sondes were balloon-borne Electrochemical Concentration Cell (ECC) $\mathrm{O}_{3}$ sondes (model 1z, En-Sci Corp., Boulder, Colorado) coupled to Väisälä radiosondes (model RS80, Väisälä USA, Woburn, Massachusetts). The accuracy of the $\mathrm{O}_{3}$ sensor varies from $\pm 1-2$ ppbv below $5 \mathrm{~km}$ to \pm 5 ppbv at $10 \mathrm{~km}$ and $\pm 20 \mathrm{ppbv}$ at $20 \mathrm{~km}$ altitude (Smit et al., 1994, 1995). Tables 1 and 2 summarize the ship tracks and locations where the $\mathrm{O}_{3}$ profiles were measured.

\section{Measured and modeled $\mathrm{O}_{3}$ profiles}

\subsection{5 profiles}

Figure 2a shows $\mathrm{O}_{3}$ profiles measured from the ship cruise of R/V Malcolm Baldrige during March and April 1995. An analysis of profiles 6 to 13 can be found in de Laat et al. (1999). Profiles 9 and 10 are also discussed in de Laat and Lelieveld (2001). For the exact location of the $\mathrm{O}_{3}$ profiles see Table 1. Profiles 6 to 13 were launched south of the ITCZ. The most striking features in profiles 6 to 13 are the low $\mathrm{O}_{3}$ mixing ratios in the marine boundary layer $\left(\mathrm{O}_{3}\right.$ de- 

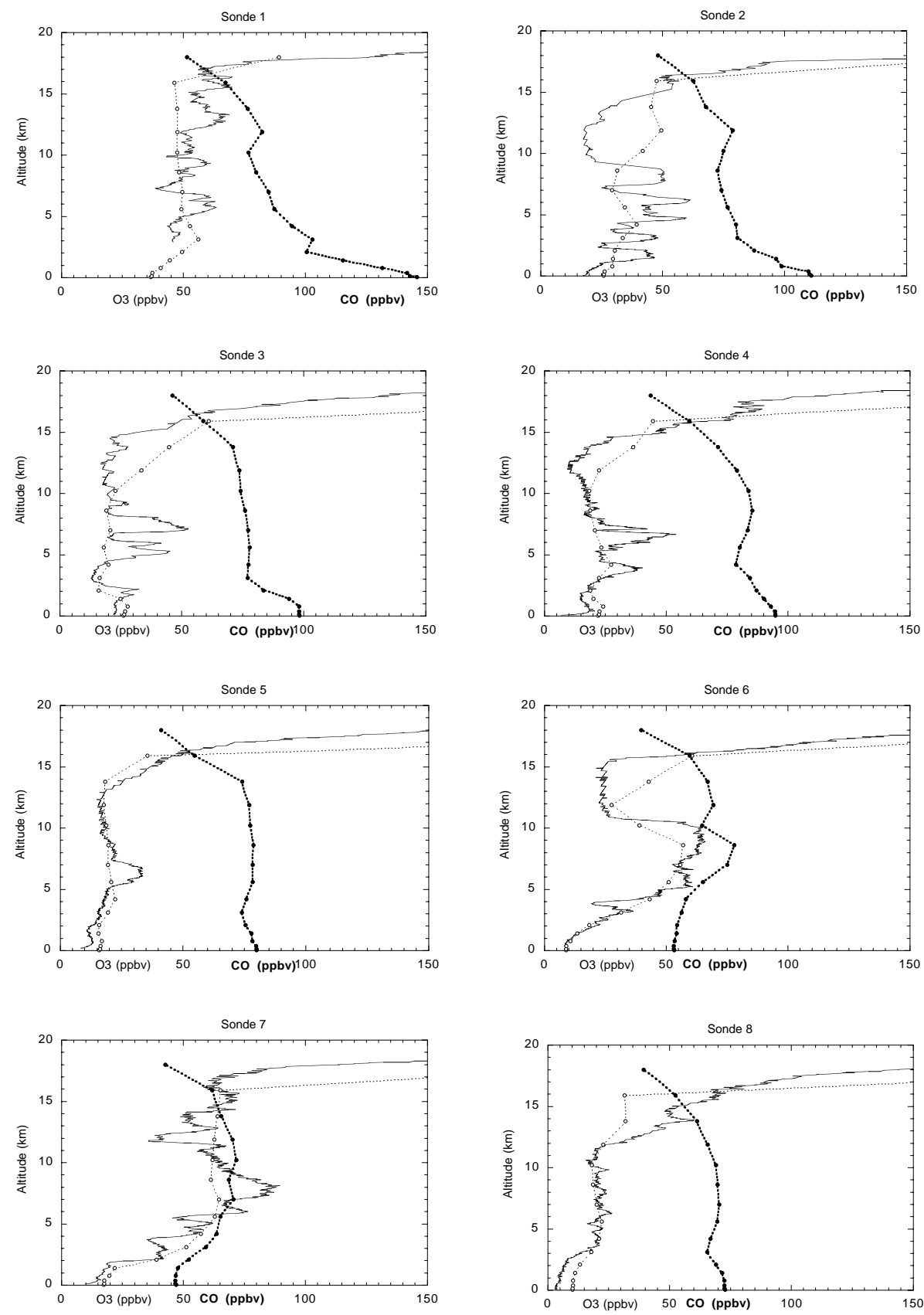

Fig. 3a. Similar to Fig. 2a but for the 1998 INDOEX profiles No 1 to 8 .

structive environment), mid-tropospheric $\mathrm{O}_{3}$ maxima, which can be attributed to biomass burning over Africa, and low upper-tropospheric $\mathrm{O}_{3}$ mixing ratios, which are likely caused by vertical transport of marine boundary layer air due to convection. Furthermore $\mathrm{O}_{3}$ laminae are present in most profiles between 14 and $17 \mathrm{~km}$, most notably profiles 6 and 7. Figure $2 \mathrm{a}$ and $\mathrm{b}$ also show the modeled $\mathrm{O}_{3}$ and $\mathrm{CO}$ profiles. The model simulates comparable absolute $\mathrm{O}_{3}$ mixing ratios and the spatial and temporal variations as observed. The model cannot simulate smaller $\mathrm{O}_{3}$ features in the profiles because of the low horizontal and vertical resolution. The low hori- zontal resolution may cause some displacement of modeled gradient compared to actual location of the gradient because the observations were done in a region with sharp horizontal gradients. This may result in discrepancies between modeled and observed $\mathrm{O}_{3}$ profiles (for example profile 9, see de Laat et al. (1999) for a detailed analysis). Modeled $\mathrm{O}_{3}$ correlates well with modeled $\mathrm{CO}$ for mid-tropospheric $\mathrm{O}_{3}$ maxima, indicating that the mid-tropospheric $\mathrm{O}_{3}$ maxima have a tropospheric origin. Backtrajectory calculations showed that the air masses originated from biomass burning regions over central Africa (de Laat et al., 1999). 

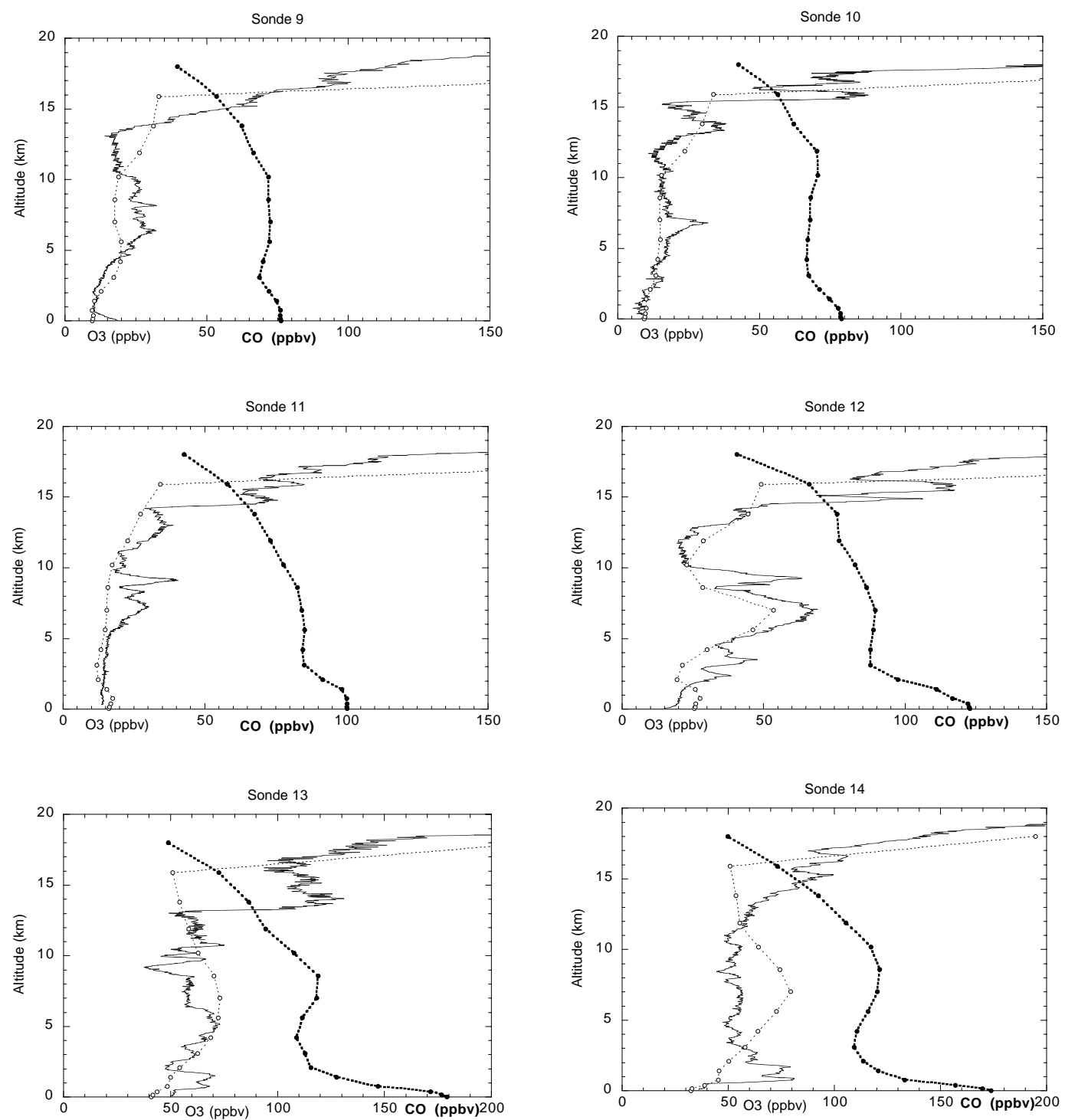

Fig. 3b. Similar to Fig. 2a but for 1998 INDOEX cruise profiles No 9 to 14 .

Figure $2 \mathrm{~b}$ also shows $\mathrm{O}_{3}$ profiles from soundings launched during the 1995 cruise of the R/V Malcolm Baldrige, which have not been published before. The ITCZ was located close to profiles 14 and 15 . Boundary layer $\mathrm{O}_{3}$ is low, whereas free tropospheric $\mathrm{O}_{3}$ is high. Upper-tropospheric $\mathrm{O}_{3}$ minima are not as pronounced as in profiles 6 to 13, while they are clearly visible in the modeled profiles. Discrepancies between the measured and modeled profiles also occur close to the ITCZ (profiles 14 to 17). It can be expected that the model cannot simulate the exact location of the ITCZ at the current model resolution because generally the convective surface area (typically $10-1000 \mathrm{~km}^{2}$ ) is much smaller that the model gridsize (typically $100000 \mathrm{~km}^{2}$ ). Further away from the ITCZ (profiles 18 to 21) this is less of a problem.

Mid-tropospheric $\mathrm{O}_{3}$ mixing ratios are generally high for all profiles, also north of the ITCZ, and are simulated by the model. As with profiles 6 to 13 in Fig. 2a, modeled midtropospheric $\mathrm{O}_{3}$ peaks are associated with high model $\mathrm{CO}$ mixing ratios.

\subsection{8 (FFP) profiles}

Figure $3 \mathrm{a}$ and $\mathrm{b}$ show vertical profiles from the $1998 \mathrm{IN}-$ DOEX IFP $\mathrm{O}_{3}$ soundings. An analysis of these profiles based on backtrajectory calculations and potential vorticity can be found in Zachariasse et al. (2000). For the details of the location and time of launch of these soundings see Table 2. The overall features of the 1998 profiles are similar to those measured in 1995: Low boundary layer $\mathrm{O}_{3}$ mixing ratios, midtropospheric maxima and minima, and upper-tropospheric $\mathrm{O}_{3}$ laminae between 14 and $17 \mathrm{~km}$ altitude. $\mathrm{O}_{3}$ profiles mea- 

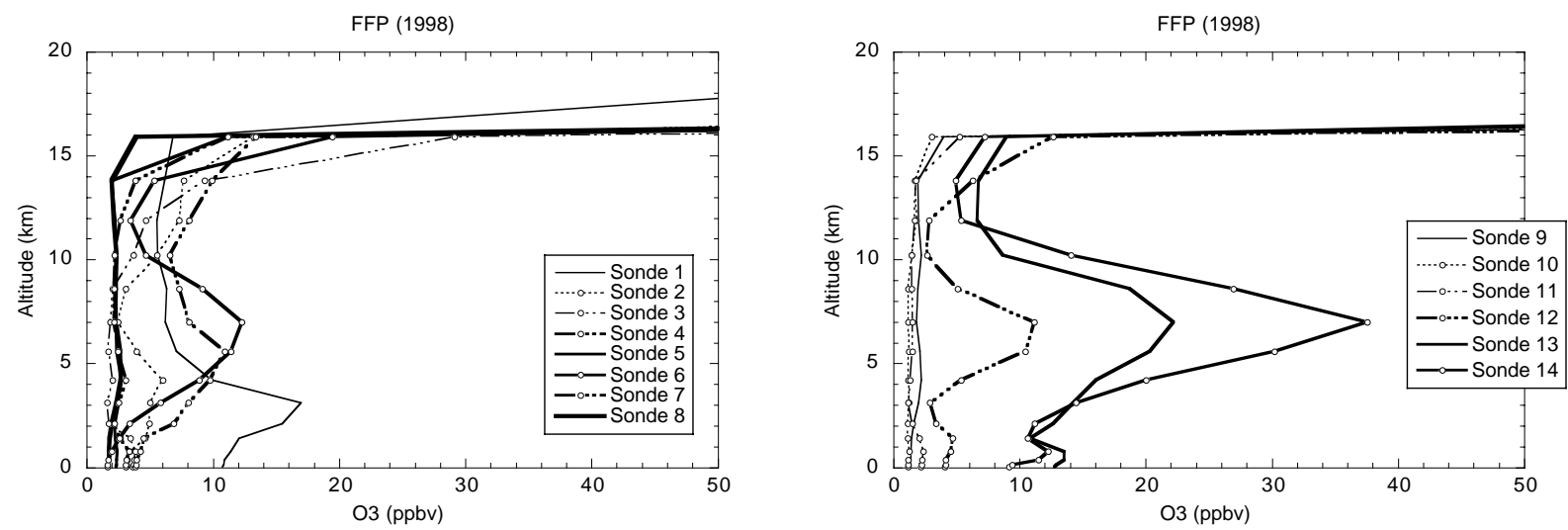

Fig. 4. Vertical profiles of $\mathrm{O}_{3}$ of stratospheric origin $\left(\mathrm{O}_{3} \mathrm{~s}\right)$ from the ECHAM model, for the 1998 profiles. The left panel shows 1998 profiles $1-8$, the right panel shows profiles 9-14. Mixing ratios in ppbv.

sured at close locations during both years are very similar (1995 profiles 7 to 9 and 1998 profiles 6 and 7). However, mid-tropospheric $\mathrm{O}_{3}$ mixing ratios are generally lower for the FFP-profiles than for the 1995 profiles. Modeled O 3 profiles are similar to measured $\mathrm{O}_{3}$ profiles. Large discrepancies only exist for profile 14 , with an observed mid-tropospheric minimum and a modeled mid-tropospheric maximum, and profile 2, for which the model does not simulate the observed upper-tropospheric minimum. Similar to the 1995 profiles, the model does not capture the upper-tropospheric $\mathrm{O}_{3}$ laminae very well, but no upper tropospheric $\mathrm{O}_{3}$ minima are present in the modeled profiles, with the exception of profiles 13 and 14. Furthermore, $\mathrm{O}_{3}$ mixing ratios increase from an altitude of $12 \mathrm{~km}$ and higher for most modeled profiles.

Modeled $\mathrm{CO}$ profiles corresponding to the measured $\mathrm{O}_{3}$ profiles are somewhat different to the modeled $1995 \mathrm{CO}$ profiles. Generally, modeled mid-tropospheric $\mathrm{CO}$ mixing ratios are lower during 1998 than during 1995. This corresponds with lower mid-tropospheric $\mathrm{O}_{3}$ mixing ratios for the 1998 profiles, which one would expect if $\mathrm{O}_{3}$ and $\mathrm{CO}$ have the same source. Boundary layer CO mixing ratios north of the ITCZ are higher compared to 1995. Considering that the FFP profiles were measured earlier in the year (March) compared to 1995 (April), the discrepancies can be explained as follows. According to de Laat and Lelieveld (2002) the strength of the boundary layer continental outflow from India to the Indian Ocean weakens considerably during March and April, lowering the boundary layer levels of pollution. Furthermore, the convective outflow in the free troposphere (divergent flow away from the convection) at the ITCZ will be balanced by the mid-tropospheric inflow of polluted air masses from the subtropics. A weak ITCZ allows the polluted free tropospheric subtropical air masses north and south of the equator to be advected further equatorward than in case of a strong ITCZ. The ITCZ is generally stronger during March than during April over the Indian Ocean. Therefore, more boundary layer air is vertically mixed at the ITCZ during March than during April. Furthermore, a stronger ITCZ causes a stronger divergent upper-tropospheric flow that can transport the "clean" air masses further away from the ITCZ. Thus, free tropospheric $\mathrm{O}_{3}$ and $\mathrm{CO}$ mixing ratios will be lower and cover a larger area during March compared to April. The result is that free tropospheric $\mathrm{O}_{3}$ and $\mathrm{CO}$ mixing ratios are lower for the 1998 profiles compared to the 1995 profiles.

The ECHAM model also provides a separate tracer for $\mathrm{O}_{3}$ that originates from the stratosphere (hereafter $\mathrm{O}_{3} \mathrm{~s}$ ). The influence of STE along the subtropical jets on tropospheric $\mathrm{O}_{3}$ can be derived for the modeled profiles using this tracer. Figure 4 shows modeled $\mathrm{O}_{3}$ s profiles for the 1998 soundings. With the exception of profiles 13 and 14, the contribution of $\mathrm{O}_{3}$ s to total tropospheric $\mathrm{O}_{3}$ is relatively small (less than $20 \%$, cf. Roelofs and Lelieveld, 1997). On the other hand, the mid-tropospheric $\mathrm{O}_{3}$ features in profiles 6, 7, 12, 13 and 14 are at least partly of stratospheric origin. The contribution of $\mathrm{O}_{3} \mathrm{~s}$ can be as high as $50 \%$ for profiles 13 and 14 .

Modeled CO mixing ratios above $12 \mathrm{~km}$ altitude decrease to approximately 50 to $60 \mathrm{ppbv}$ around $18 \mathrm{~km}$ altitude (see Figs. 2 and 3). Modeled free tropospheric $\mathrm{CO}$ mixing ratios higher than 50 to $60 \mathrm{ppbv}$ indicates a tropospheric origin, while lower mixing ratios indicate a stratospheric origin (unless $\mathrm{O}_{3}$ mixing ratios are low, which indicates vertical mixing of very clean marine boundary layer air masses). Such low CO mixing ratios are not modeled for any of the 1998 (or 1995) profiles. Interestingly, the highest $\mathrm{O}_{3}$ s contribution is modeled for profiles 13 and 14, which also showed the highest mid-tropospheric CO mixing ratios modeled for 1998. Based on the modeled profiles and the correlation between $\mathrm{O}_{3}$ and CO peaks for both 1995 and 1998 we can conclude that the major sources of mid-tropospheric $\mathrm{O}_{3}$ maxima are of tropospheric origin. According to 1998 profiles 13 and 14, there also may be a relation between STE and the advection of $\mathrm{O}_{3}$ and $\mathrm{CO}$ rich tropospheric air. 


\section{Mid-tropospheric $\mathrm{O}_{3}$ and $\mathrm{CO}$ maxima: source region and advection mechanism}

The model-observation comparison yields that the source of the mid-tropospheric $\mathrm{O}_{3}$ and $\mathrm{CO}$ maxima could very well be tropospheric. Using the model we can try to determine what the source regions are and how the pollution is advected to the Indian Ocean. For that, we first need to understand the dynamical processes in this region. Africa is an important source region of pollutant emission of $\mathrm{NO}_{\mathrm{X}}$ and $\mathrm{CO}$ (Crutzen and Carmichael, 1993; Roelofs et al., 1997a). In particular, biomass burning is the major source of these pollutants (Crutzen and Andrae, 1990; Crutzen and Carmichael, 1993; Hao and Liu, 1994; Galanter et al., 2000; de Laat et al., 2001). CO production will also occur indirectly by way of oxidation of higher hydrocarbons, which are additionally emitted by biomass burning. The biomass-burning season in Africa is very much dependent on the time of year (Hao and Liu, 1994). Generally, biomass burning occurs during the local dry season, causing a maximum in pollution levels. $\mathrm{CO}$ mixing ratios are highest near the surface, and lower in the free troposphere aloft. On the other hand, tropospheric $\mathrm{O}_{3}$ is mostly produced by a catalytic reaction chain involving $\mathrm{NO}_{X}$ (e.g. Graedel and Crutzen, 1993). Not only will $\mathrm{O}_{3}$ be produced close to the source regions of its precursors, but as the precursors are transported, it will also be produced during advection (Chatfield and Delaney, 1990; Pickering et al., 1992). This so-called "mix-then-cook" mechanism, in combination with $\mathrm{O}_{3}$ removal that occurs at the surface, causes $\mathrm{O}_{3}$ mixing ratios to be generally higher in the free troposphere than at the surface. Furthermore, free tropospheric pollution is mostly removed by reaction with $\mathrm{OH}$. In turn, $\mathrm{OH}$ depends largely on the presence of moisture $\left(\mathrm{H}_{2} \mathrm{O}\right)$. Because moisture decreases with altitude, the lifetime of $\mathrm{O}_{3}$ and its precursors $\mathrm{CO}$ and $\mathrm{NO}_{\mathrm{X}}$ can become quite long, enabling plumes of pollution to travel long distances, especially under dry conditions as they occur in the descending branches of the Hadley circulation.

There exists a distinct difference in the tropospheric chemical composition over Africa between regions north and south of the equator due to differences in meteorology, emissions and photochemistry. Major convection occurs south of the equator during the winter monsoon period (Hastenrath, 1988), following the maximum in solar insolation, while biomass burning mainly occurs north of the equator (Hao and $\mathrm{Liu}, 1994)$. The maxima in average modeled surface $\mathrm{O}_{3}$ and CO mixing ratios for February and March 1998 occur north of the ITCZ, caused by high pollutant emissions (dry season) and active photochemistry (less clouds). At $10 \mathrm{~km}$ altitude only a maximum in $\mathrm{CO}$ is simulated, and it is located further south. Ostensibly the maximum mixing ratios at the surface and in the free troposphere should occur at the same (geographical) location. However, although maximum surface pollution occurs north of the ITCZ, surface pollution levels over Austral Africa are still high (>200 ppbv). Hence the upper-tropospheric $\mathrm{CO}$ maximum simply reflect the convective areas. Actually, because there is a latitudinal pollution gradient at the surface over Austral African, the maximum free tropospheric $\mathrm{CO}$ mixing ratios are found over the area where both convection and the highest surface pollution levels occur (Fig. 5). For $\mathrm{O}_{3}$ it is more difficult to distinguish a free tropospheric maximum, due to the influence of stratospheric $\mathrm{O}_{3}$ and the ongoing $\mathrm{O}_{3}$ formation, that can occur after air masses are advected away from the convection. However, subtracting the modeled stratospheric $\mathrm{O}_{3}$ tracer from total $\mathrm{O}_{3}$ yields the amount of $\mathrm{O}_{3}$ that is produced in the troposphere. Figure 6 shows the average residual $\mathrm{O}_{3}$ mixing ratios at 10 $\mathrm{km}$ altitude for February and March 1998. Maximum mixing ratios occur over Africa and the tropical Atlantic, although the region with high mixing ratios is more widespread for residual $\mathrm{O}_{3}$ than for $\mathrm{CO}$, reflecting the different source mechanisms for both species.

Figure 5 also shows that at the $10 \mathrm{~km}$ altitude level $\mathrm{CO}$ is advected (on average) from central Africa along the northern and southern hemispheric subtropical jets (NH-STJ and SHSTJ) at $20^{\circ}-30^{\circ}$ towards the Indian Ocean. A similar pattern exists for residual $\mathrm{O}_{3}$ along NH-STJ (Fig. 6). Advection of $\mathrm{O}_{3}$ from central Africa also occurs along the SH-STJ during February 1998, while it appears to be absent in CO during the same month. However, this probably is a spurious observation reflecting the very nature of upper-tropospheric $\mathrm{CO}$. Free tropospheric $\mathrm{CO}$ mixing ratios (as well as residual $\mathrm{O}_{3}$, see Fig. 6) are lower during February compared to March 1998 due to lower convective activity. Hence less pollutants are transported from the boundary layer to the troposphere. At the same time STE will transport CO depleted air to the troposphere along the SH-STJ. Consecutive mixing between stratospheric and tropospheric air lowers $\mathrm{CO}$ mixing ratios, masking the "CO-pollution" plume which is visible in the residual $\mathrm{O}_{3}$ field along the SH_STJ.

The mechanism responsible for the advection along the subtropical jets can be determined from Figs. 7a and b, showing modeled $\mathrm{O}_{3}, \mathrm{CO}, \mathrm{O}_{3} \mathrm{~s}$ and $\mathrm{O}_{3} \mathrm{t}$ and the wind fields for two days during March 1998 at $10 \mathrm{~km}$ altitude (10 and 13 March, Day of Year (DOY) 69 to 72). For clarity, only CO mixing ratios above $100 \mathrm{ppbv}, \mathrm{O}_{3}$ mixing ratios above $70 \mathrm{ppbv}, \mathrm{O}_{3} \mathrm{~s}$ mixing ratios above $50 \mathrm{ppbv}$ and $\mathrm{O}_{3} \mathrm{t}$ mixing ratios above 40 ppbv are shown.

On DOY 69, high CO mixing ratios are located over central Africa with corresponding $\mathrm{O}_{3}$ mixing ratios reaching 70 ppbv. A wave in the NH-STJ is approaching from the west (at $0^{\circ} \mathrm{E}$ ), causing winds in front of the wave to change from westerly to southwesterly. The divergent flow (convective outflow) at $10 \mathrm{~km}$ altitude over central Africa is relatively constant. Therefore, the wave at the STJ causes an acceleration of the flow just south of the wave. This initiates advection of polluted African air masses. North and south of the NH-STJ $\mathrm{O}_{3}$ mixing ratios are high, reflecting the change in the height of the tropopause north and south of the STJ. Moreover, at the latitude with the highest wind speeds the 

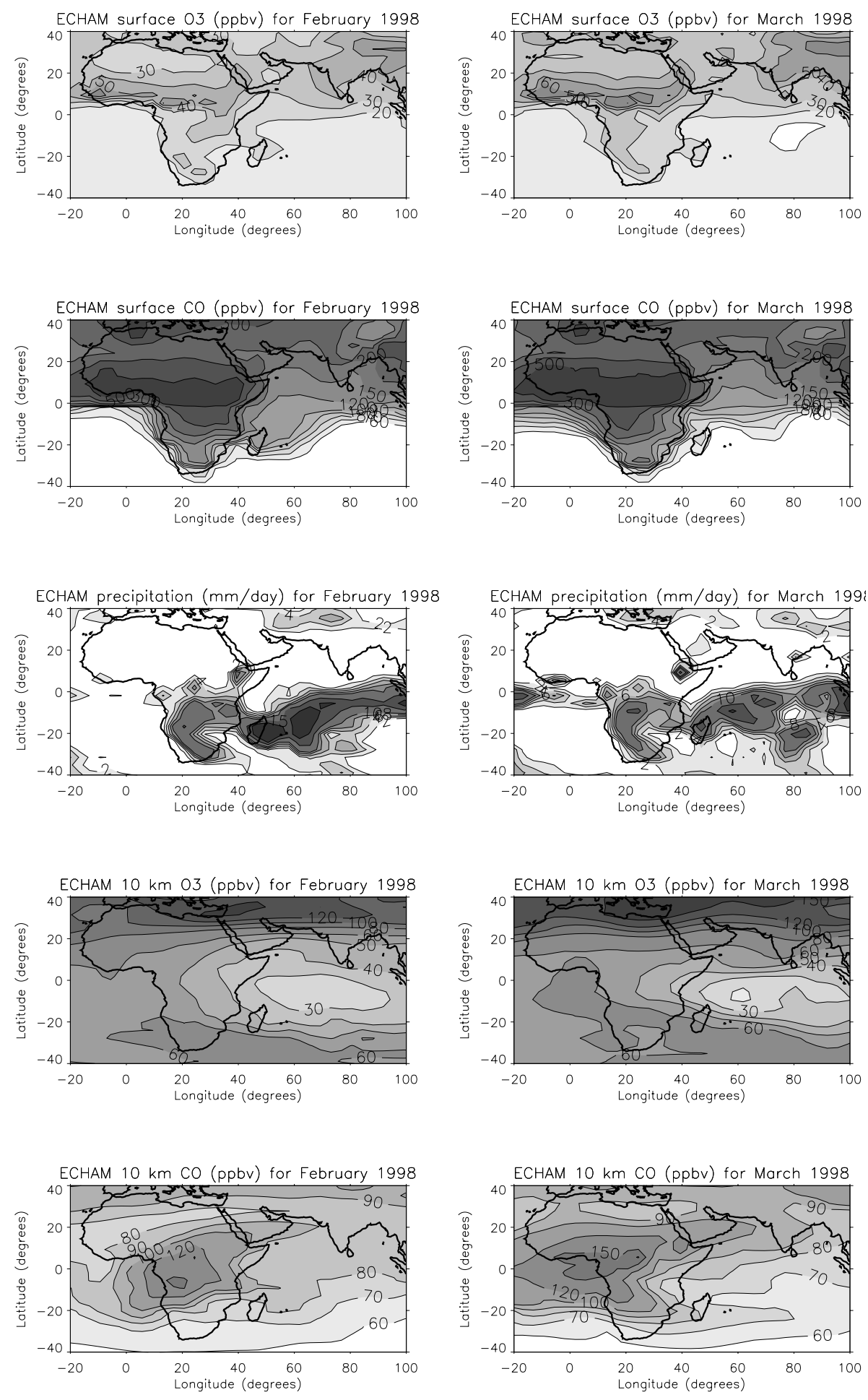

Fig. 5. Monthly averaged ECHAM results for the INDOEX region, February and March 1998: surface $\mathrm{O}_{3}$ and $\mathrm{CO}$, precipitation and $10 \mathrm{~km}$ altitude $\mathrm{O}_{3}$ and CO. Mixing ratios in ppbv, precipitation in $\mathrm{mm}_{\text {day }}{ }^{-1}$.

largest gradients in $\mathrm{O}_{3}$ occur. At the SH-STJ the increase in $\mathrm{O}_{3}$ mixing ratios is not as distinct as along the NH-STJ. No east-west oriented latitudinal $\mathrm{O}_{3}$ gradient exists along the $\mathrm{SH}-\mathrm{STJ}$, opposite to the NH-STJ. High $\mathrm{O}_{3}$ mixing ratios occur in bands that are associated with the frontal zones of low mid-latitude low-pressure areas. The cross-frontal circulation causes strong downward motions just behind the front, transporting $\mathrm{O}_{3}$ from the stratosphere to the troposphere. The differences in $\mathrm{O}_{3}$ mixing ratios along the NH-STJ and SHSTJ reflect the differences in the dynamical structure of the 

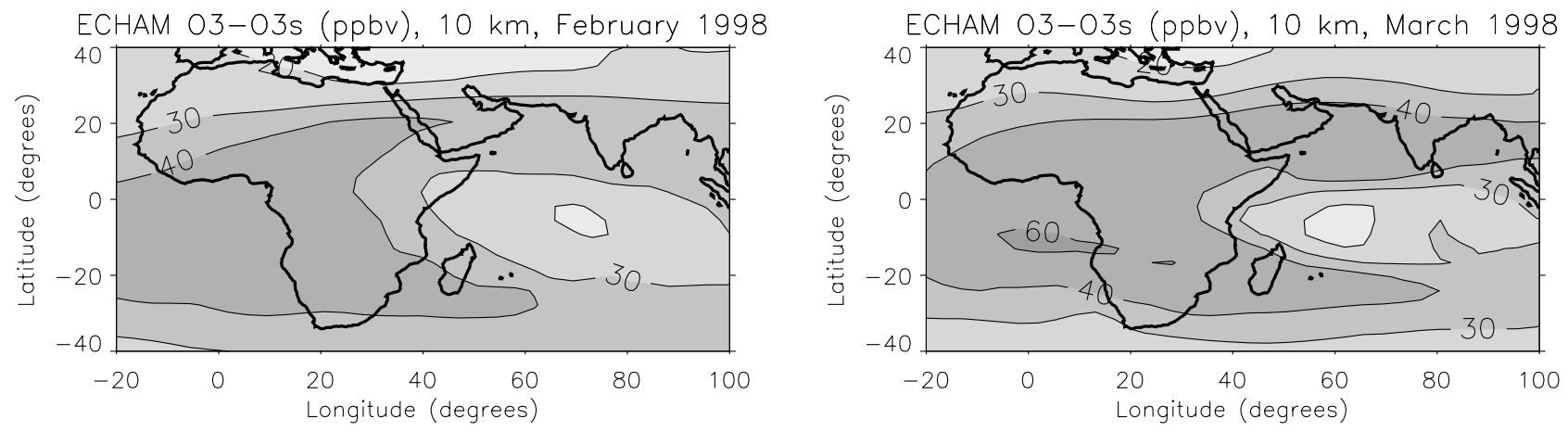

Fig. 6. Monthly averaged ECHAM residual $\mathrm{O}_{3}\left(\mathrm{O}_{3}\right.$ minus $\left.\mathrm{O}_{3} \mathrm{~s}\right)$ for February and March 1998 at $10 \mathrm{~km}$ altitude in ppbv.

STJ. The NH-STJ is generally stronger and more persistent than the SH-STJ (Hastenrath, 1998), which results in an eastwest oriented NH-STJ and a more meandering SH-STJ. At the same time, a band with high $\mathrm{O}_{3}$ is located along the SHSTJ over the southern tip of Africa $\left(30^{\circ} \mathrm{S}, 25^{\circ} \mathrm{E}\right)$. Winds change from southwest to west at this band, indicative of a frontal zone.

On DOY 72 the wave along the NH-STJ has advanced to the Arabian Sea, with advection of CO-rich air masses in the wake of the wave. The polluted air masses have advanced to over India. In the wake of the wave the circulation changes from westerly to northwesterly, thereby injecting the polluted air masses into the tropics. At the same time $\mathrm{O}_{3}$ s descends into the tropical troposphere at the wave, but remains north of the African pollution. This STE over India may be enhanced by the interaction of the wave with the Himalayas and/or the Tibetan plateau. The frontal zone along the SHSTJ has advanced to $70^{\circ}$ E. Polluted African air masses are advected eastward north of the frontal zone. $\mathrm{O}_{3} \mathrm{~S}$ is transported downwards south of the frontal zone. The high $\mathrm{O}_{3} \mathrm{t}$ mixing ratios are clearly associated with high $\mathrm{CO}$ mixing ratios. Furthermore, high $\mathrm{O}_{3} \mathrm{~s}$ and $\mathrm{O}_{3}$ t mixing ratios do not occur simultaneously, but are somewhat separated.

As both the "northern wave" and the "southern front" continue to advance further east, the flow along the subtropical jets becomes westerly again, which will shut down the advection of polluted air masses from central Africa, while at the same time STE vanishes. Polluted air masses (CO and $\mathrm{O}_{3}$, the latter both from tropospheric and stratospheric origin) have entered the descending branches of the Hadley circulation, and will be slowly advected towards the ITCZ. The pollution is gradually removed during this advection.

This sequence occurs every time waves or fronts travel along the subtropical jets. It is important to note that, as these fronts have passed the African continent, they will be rich in $\mathrm{O}_{3}$ both poleward (stratospheric $\mathrm{O}_{3}$ ) and equatorward (tropospheric pollution) of the subtropical jets. Therefore, high free tropospheric $\mathrm{O}_{3}$ mixing ratios over the Indian Ocean are not an indication of a stratospheric origin, even though trajectories indicate advection along the subtropical jets. Low humidity is also not an indicator for a stratospheric origin because air masses dry out very rapidly in the downward branch of the Hadley circulation. Frontal mixing of air masses may complicate the situation even more.

\section{Summary and discussion}

The analysis of model simulations reveals the mechanism behind the mid-tropospheric $\mathrm{O}_{3}$ peaks in the downward branches of the Hadley circulation. During the winter monsoon period a mid and upper-tropospheric "reservoir" of polluted air masses with high $\mathrm{O}_{3}$ and $\mathrm{CO}$ mixing ratios is present over central Africa. This "reservoir" is fueled by surface emissions in equatorial Africa. Upper-tropospheric divergence due to convective outflow causes the pollution to slowly propagate north and south over Africa. Waves or frontal zones propagate along the subtropical jets and cause winds along the equatorward edges of the STJ to change from an east-west direction to south-west (NH) or northwest (SH). This causes advection of polluted air masses from the African reservoir to the edge of the subtropical jets. At the STJ the polluted air masses are advected eastward in front of the frontal zone. The polluted air masses enter the downward branches of the Hadley circulation over the Indian Ocean, causing an increase in $\mathrm{O}_{3}$ and $\mathrm{CO}$ mixing ratios. In addition to this mechanism air masses of stratospheric origin may enter the troposphere at the back of the frontal zones that propagate along the STJ. However, the model simulations also indicate that $\mathrm{O}_{3}$ s is not advected that deep into the tropics. Furthermore, due to their slow downward motion over the subtropical Indian Ocean the polluted tropospheric air masses dry out. This results in very low humidity, which could easily be misinterpreted as a stratospheric signature, while it is simply a result of local dynamics. Figures 8 and 9 further illustrate the relationship between $\mathrm{O}_{3}$ and $\mathrm{CO}$ by showing the correlations between modeled $\mathrm{CO}, \mathrm{O}_{3}, \mathrm{O}_{3}$ s and residual $\mathrm{O}_{3}$. Figure 8 shows a latitudinal cross-section between $45^{\circ} \mathrm{S}$ and $35^{\circ} \mathrm{N}$ along $69^{\circ} \mathrm{E}$ for February and March 1998. Several different regimes can be distinguished. 

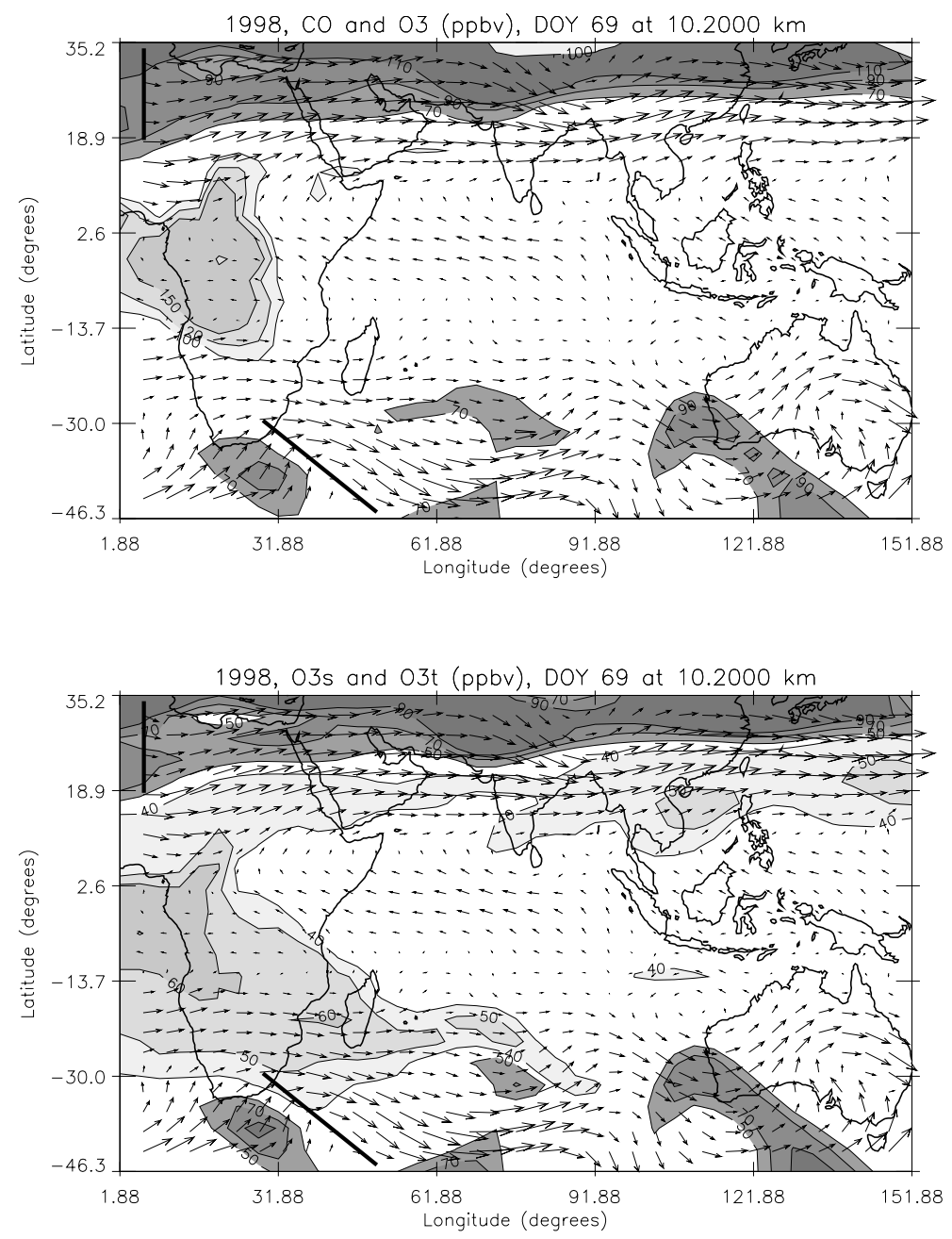

Fig. 7a. ECHAM model results at 10 $\mathrm{km}$ altitude over the INDOEX region for 10 March (DOY 69, 00:00 GMT): wind field in arbitrary units. Upper panel: CO (contour intervals: 100, 120 and $150 \mathrm{ppbv}$ ) in lighter colors, $\mathrm{O}_{3}$ (contour intervals: 70, 90 and 110 ppbv) in darker colors. Lower panel: $\mathrm{O}_{3} \mathrm{t}$ (contour intervals: 40, 50, and $60 \mathrm{ppbv}$ ) in lighter colors, $\mathrm{O}_{3}$ s (contour intervals: 50, 70 and 90 ppbv) in darker colors. The location of the two waves/frontal zones that are described in the text are indicated by the thick black lines.
In the tropopause region there is a negative correlation between $\mathrm{CO}$ and $\mathrm{O}_{3} / \mathrm{O}_{3}$ s. Tropospheric $\mathrm{O}_{3}$ mixing ratios are relatively low compared to stratospheric $\mathrm{O}_{3}$ mixing ratios, while tropospheric $\mathrm{CO}$ mixing ratios are high compared to stratospheric $\mathrm{CO}$ mixing ratios (CO is photodissociated in the stratosphere). This causes a negative correlation between $\mathrm{CO}$ and $\mathrm{O}_{3}$. This is also reflected in the positive correlation between $\mathrm{CO}$ and residual $\mathrm{O}_{3}\left(\mathrm{O}_{3} \mathrm{t}\right)$.

In the southern hemispheric MBL the correlation between $\mathrm{CO}$ and $\mathrm{O}_{3}$ is negative, also for residual $\mathrm{O}_{3}$. These air masses can be considered "clean". $\mathrm{O}_{3}$ and $\mathrm{CO}$ mixing ratios are low. $\mathrm{CO}$ mixing ratios are mainly determined by $\mathrm{OH}$ breakdown because sources are small. The $\mathrm{OH}$ concentration is strongly dependent on $\mathrm{O}_{3}$ mixing ratios. Thus, if $\mathrm{O}_{3}$ is low, $\mathrm{OH}$ concentrations will be low hence $\mathrm{CO}$ removal will be low and $\mathrm{CO}$ mixing ratios remain higher. Vice versa, if $\mathrm{O}_{3}$ is higher, $\mathrm{OH}$ will be higher and $\mathrm{CO}$ mixing ratios will be lower.

At the ITCZ there is a positive correlation between $\mathrm{CO}$ and $\mathrm{O}_{3}$. North of the ITCZ air masses are polluted with high $\mathrm{CO}$ and $\mathrm{O}_{3}$ yields. In polluted air masses $\mathrm{CO}$ and $\mathrm{O}_{3}$ have a posi- tive correlation: more pollution (more $\mathrm{CO}$ ) leads to more $\mathrm{O}_{3}$. At the same time, southern hemispheric air masses are clean, and compared to northern hemispheric air masses, relatively low in $\mathrm{O}_{3}$ and $\mathrm{CO}$. Thus, changes from $\mathrm{SH}$ to $\mathrm{NH}$ air masses cause a similar change in both $\mathrm{CO}$ and $\mathrm{O}_{3}$. Since this positive correlation also exists for $\mathrm{CO}$ and $\mathrm{O}_{3} \mathrm{~s}$, the Indian subcontinent apparently is also a "source" of stratospheric $\mathrm{O}_{3}$. Note however that the high correlation does not mean that $\mathrm{O}_{3} \mathrm{~s}$ is abundant.

Higher up (in altitude) at the ITCZ the $\mathrm{CO}-\mathrm{O}_{3}$ correlation becomes negative. Compared to the MBL the free troposphere is high in $\mathrm{O}_{3}$, but low in $\mathrm{CO}$. Thus, if MBL air masses are mixed vertically, $\mathrm{O}_{3}$ mixing ratios will decrease whereas $\mathrm{CO}$ mixing ratios will increase.

In the free troposphere north of the equator two regimes can be identified. At $20^{\circ} \mathrm{N}$ a "tongue" of negatively correlated $\mathrm{CO}$ and $\mathrm{O}_{3}$ s descends into the troposphere .This is stratospheric air entering the troposphere (hence the negative correlation). At the same time, there is a positive correlation between $\mathrm{CO}$ and residual $\mathrm{O}_{3}$, caused by the advec- 

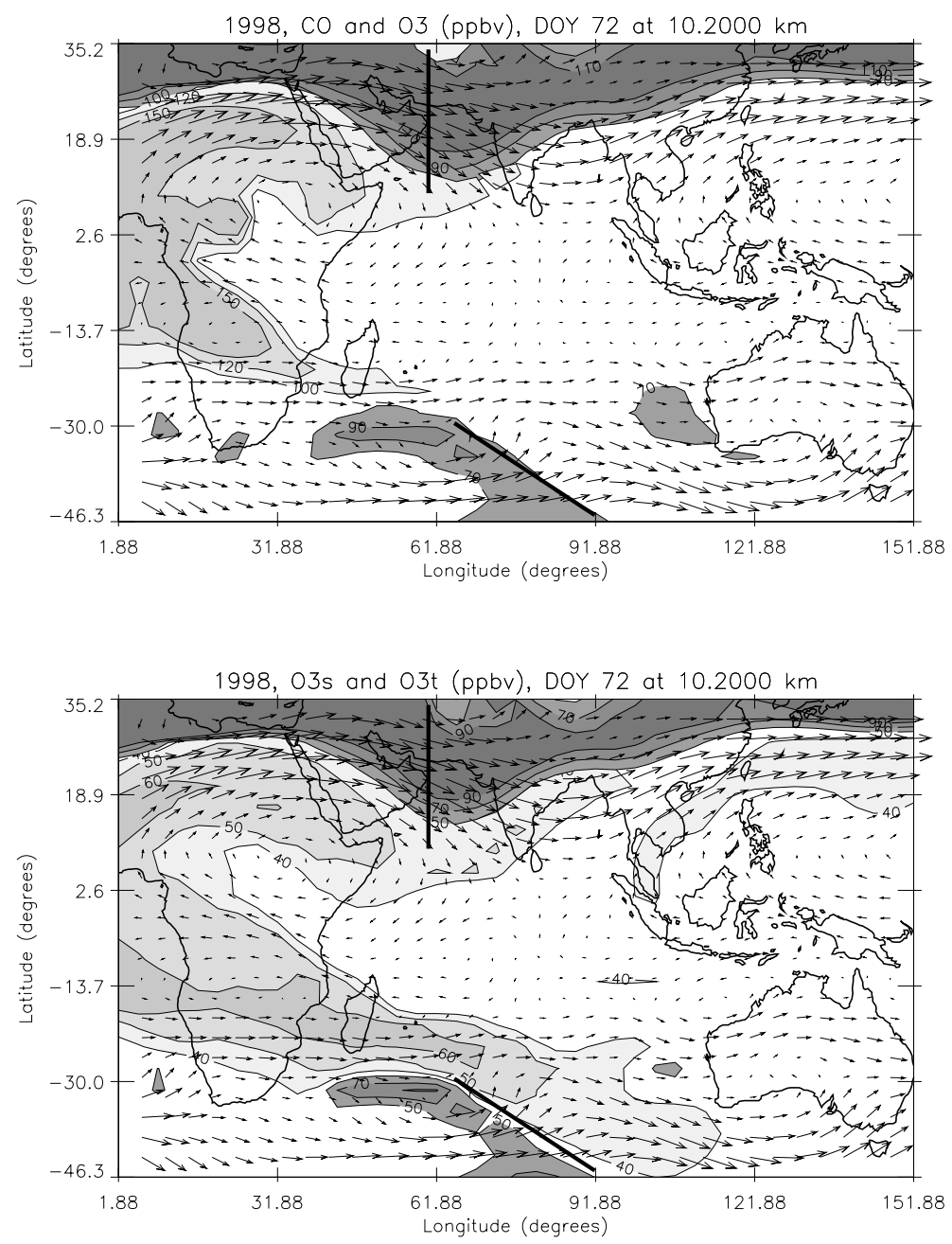

Fig. 7b. Similar to Fig. 8a, but for 13 March (DOY 72 00:00 GMT). tion of polluted African air masses. Close to the equator the $\mathrm{CO}-\mathrm{O}_{3}$ s correlation becomes positive, indicating some mixing between stratospheric air masses and polluted African air masses.

The tropospheric origin of free tropospheric air masses over India is also reflected in Fig. 9, showing the correlations at $8.6 \mathrm{~km}$ altitude for the INDOEX region. For $\mathrm{CO}$ and $\mathrm{O}_{3}$ the regions with high correlations are small, but they reflect the ambiguous nature of the air masses of free tropospheric air masses. A positive correlation (tropospheric) exists over eastern Africa towards southern India, while over northern India the correlation is negative (stratospheric). This pattern is more pronounced in the $\mathrm{CO}-\mathrm{O}_{3} \mathrm{~s}$ and $\mathrm{CO}$-residual $\mathrm{O}_{3}$ correlation. $\mathrm{CO}$ is strongly correlated with residual $\mathrm{O}_{3}$ and strongly anti-correlated with stratospheric $\mathrm{O}_{3}$. Only close to the CO-source region (convection over Austral Africa) these correlations become small, due to the different chemical nature of $\mathrm{CO}$ and $\mathrm{O}_{3}$ close to pollution sources. The positive correlation between $\mathrm{CO}$ and $\mathrm{O}_{3}$ s just east of equatorial Africa could be caused by the mixing that of African pollution and stratospheric air in the free troposphere over India. The general flow at the equator is westward, transporting the free tropospheric Indian air masses towards Africa. However, note that in tropical equatorial regions the contribution of $\mathrm{O}_{3} \mathrm{~s}$ to total $\mathrm{O}_{3}$ is small $(<10 \%$, Roelofs and Lelieveld, 1997).

There exist other studies that yield additional clues to African pollution as source of free tropospheric $\mathrm{O}_{3}$ over the Indian Ocean. The analysis of Thompson et al. (1996) and Chatfield et al. (1996) for the SAFARI (Southern Africa Fire Atmospheric Research Initiative) and TRACE A (Transport and Atmospheric Chemistry Near the Equator-Atlantic) campaigns show a remarkable resemblance with the analysis presented in this study, even though the above mentioned studies were carried out for October 1992. Part of the mid-tropospheric air masses over central and southern Africa are advected southeast and subsequently along the SH-STJ eastward over the southern Indian Ocean (plate 3 and 4 of Thompson et al., 1996; Fig. 1 of Chatfield et al., 1996). Furthermore, part of the air masses are also advected to northern Africa and then along the NH-STJ eastward over southern 
ECHAM correlation, february + March 1998, 69 E
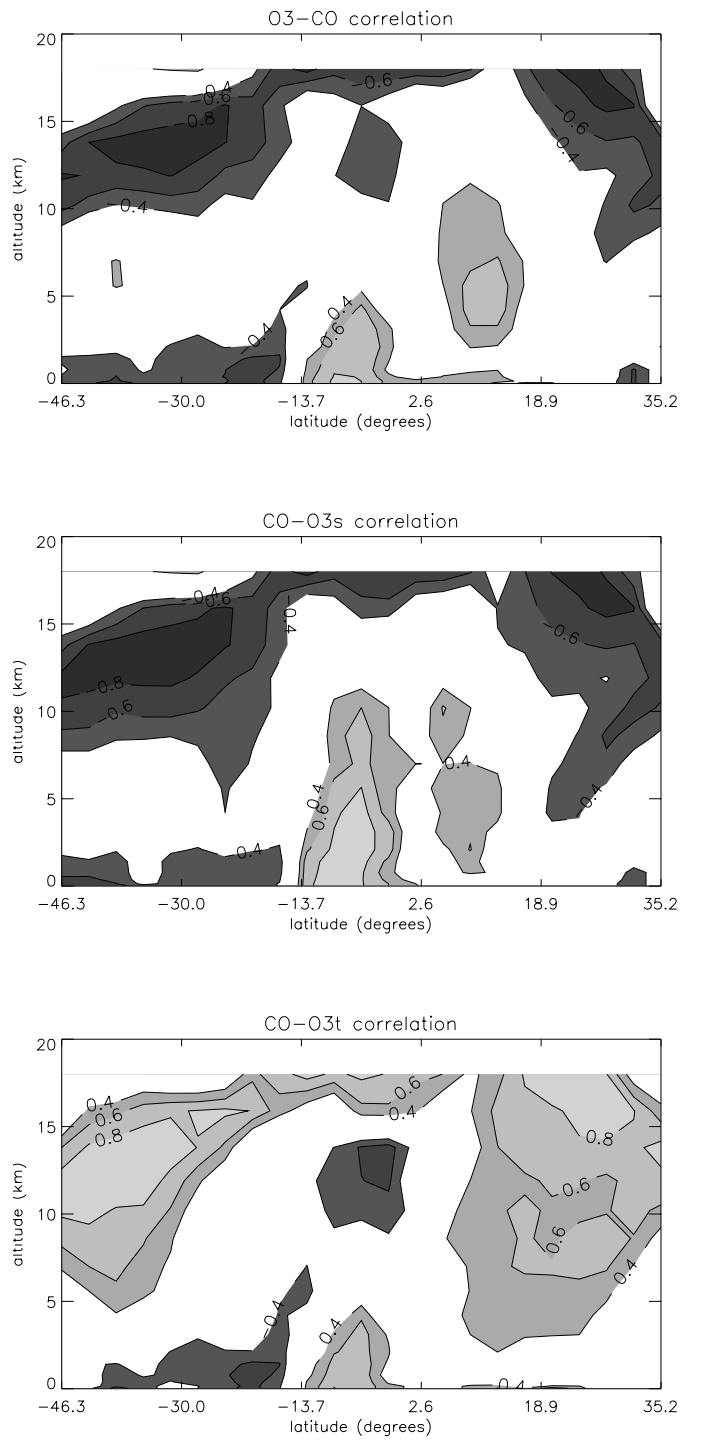

Fig. 8. Correlation coefficients between modeled (a) $\mathrm{CO}$ and $\mathrm{O}_{3}$, (b) $\mathrm{CO}$ and $\mathrm{O}_{3} \mathrm{~s}$ and (c) $\mathrm{CO}$ and residual $\mathrm{O}_{3}\left(\mathrm{O}_{3}-\mathrm{O}_{3} \mathrm{~s}\right)$ for a latitudinal cross-section along $69^{\circ} \mathrm{E}$, between $45^{\circ} \mathrm{S}$ and $35^{\circ} \mathrm{N}, 0$ and 20 km altitude, February and March 1998.

Asia (plate 4 of Thompson et al., 1996).

The model simulates the average profile structure as measured, although discrepancies exist. There may be several different reasons for the existence of the discrepancies: missing or wrong chemistry, missing or wrong advection processes, errors in the ECMWF analyses, etc. However, the existence of discrepancies does not necessarily mean that the model results are "wrong". In order to "believe" the model result they must meet two criteria: the model should be able to simulate the average measured mixing ratios, and the model should be able to simulate the spatial and temporal

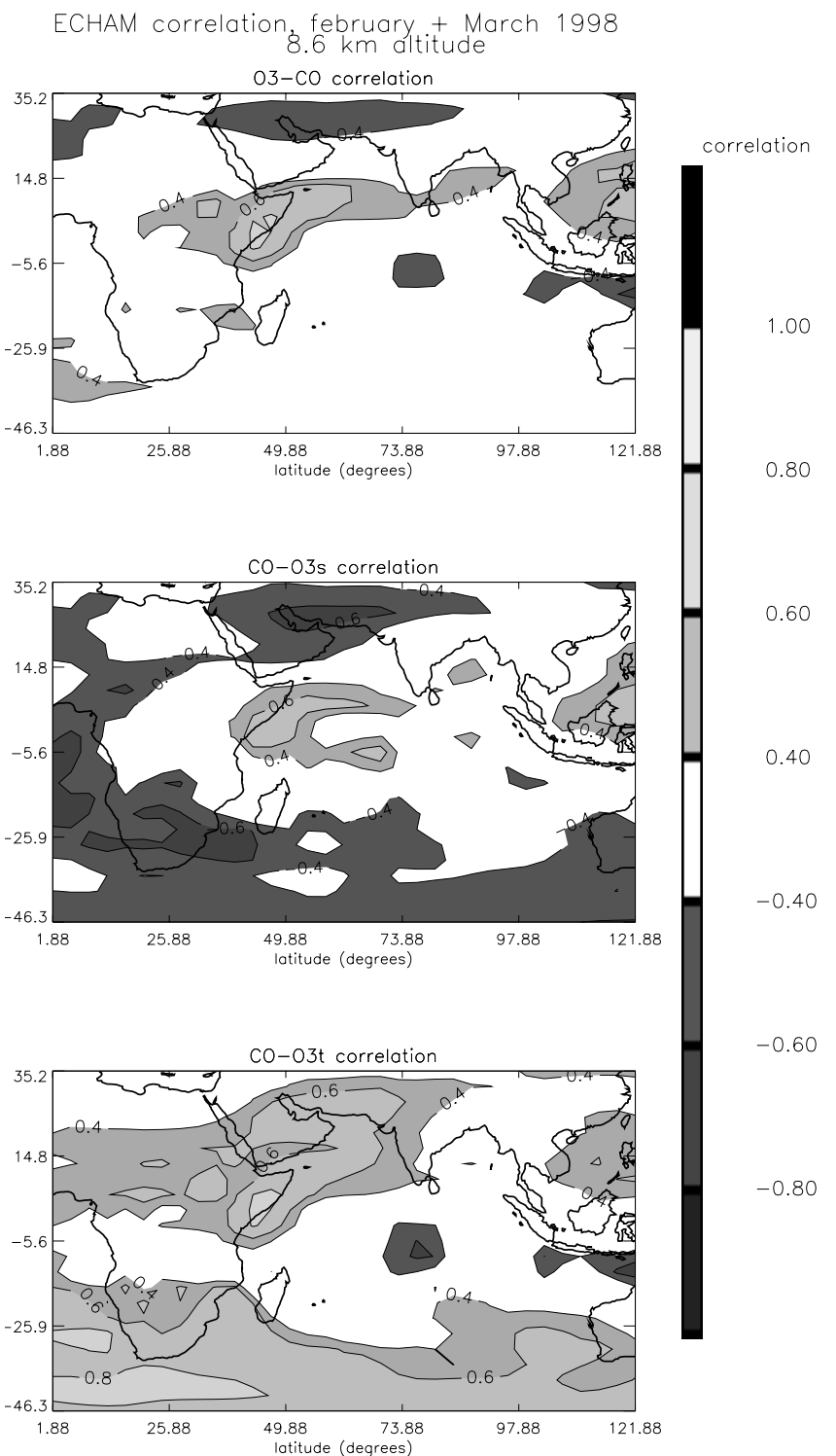

Fig. 9. Correlation coefficients between modeled (a) $\mathrm{CO}$ and $\mathrm{O}_{3}$, (b) $\mathrm{CO}$ and $\mathrm{O}_{3} \mathrm{~s}$ and (c) $\mathrm{CO}$ and residual $\mathrm{O}_{3}\left(\mathrm{O}_{3}-\mathrm{O}_{3} \mathrm{~s}\right)$ for the INDOEX region at $8.6 \mathrm{~km}$ altitude, February and March 1998.

variability as observed. The model does simulate the average $\mathrm{O}_{3}$ mixing ratios for most profiles. More importantly, it also simulates the spatial variability. Note for example that 1998 profiles 5 and 6 are taken at a distance of approximately $6^{\circ}$ degrees. At T30 resolution that is less than two gridpoints. Mid-tropospheric $\mathrm{O}_{3}$ mixing ratios increase from $20 \mathrm{ppbv}$ in profile 5 to $6 \mathrm{ppbv}$ in profiles 6 . The model simulates both profiles, showing that it is capable of capturing the observed variability.

There is a striking discrepancy between measured and modeled $\mathrm{O}_{3}$ in 1998 profile 14 (and to a lesser extent in profile 13): in the measured profile there is a mid-tropospheric 
$\mathrm{O}_{3}$ minimum, whereas in the modeled profile there is maximum. This hints at a mis-representation of one or more processes in the model. The (measured) maximum just above the boundary layer is though to be related to the local sea breeze circulation at the Indian Coasts (de Laat et al., 2001; Leon et al., 2001). Similar layers have also been reported for aerosol measurements (Leon et al., 2001; Müller et al., 2001; Reiner et al., 2001), CO (de Laat et al., 2001; Reiner et al., 2001), acetone, acetonitrile and $\mathrm{SO}_{2}$ (Reiner et al., 2001). The sea breeze circulation causes polluted continental air masses to be lifted above the (marine) boundary layer after which they are advected from the continent to the ocean. The pollution will be restricted to a shallow layer above the (marine) boundary layer because of the large-scale subsidence over the northern Indian Ocean (the downward branch of the Hadley circulation). The ECHAM model resolution is too coarse to simulate the sea-breeze circulation. Disregarding this maximum (which is smaller in profile 13: further away from the continent), the tropospheric $\mathrm{O}_{3}$ profile is more or less constant up to $12 \mathrm{~km}$ altitude. Figure 4 showed that for modeled 1998 profiles 13 and 14 there was large contribution of $\mathrm{O}_{3} \mathrm{~s}$, caused by the passage of a wave in NH-STJ over northern India. Apparently the contribution of $\mathrm{O}_{3} \mathrm{~s}$ is too large in the model, which fits in nicely with a study by Siegmund et al. (1996), who showed that at the current model resolution (T30) the cross-tropopause flux (CTF) along $30^{\circ} \mathrm{N}$ is larger compared to simulations at higher resolutions. It is believed that the models more realistically simulate the CTF at higher horizontal resolution. In addition, the model may have problems simulating the exact location of the event. A displacement could cause spurious advection of $\mathrm{O}_{3} \mathrm{~s}$.

\section{Conclusions}

In this study I have shown that the nudged ECHAM model realistically simulates $\mathrm{O}_{3}$ profiles from two pre-INDOEX campaigns, both their spatial and temporal variability. The subtropical Indian Ocean atmosphere outside the ITCZ consists of low boundary layer $\mathrm{O}_{3}$, mid-tropospheric $\mathrm{O}_{3}$ maxima, either $\mathrm{O}_{3}$ minima or maxima at the convective outflow region $(8-12 \mathrm{~km})$, and $\mathrm{O}_{3}$ laminae between the convective outflow region and the tropopause. At the $\mathrm{ITCZ} \mathrm{O}_{3}$ mixing ratios are generally low throughout the troposphere due to extensive vertical mixing of MBL air masses by convection. The model simulations show that for the mid-tropospheric $\mathrm{O}_{3}$ maxima $\mathrm{CO}$ mixing ratios are high as well. The major source region of the enhanced $\mathrm{CO}$ mixing ratios is free tropospheric African pollution. The pollution is advected from the source regions over equatorial Africa towards the subtropical jets, then along the subtropical jets towards the Indian Ocean, where part of the pollution enters the descending branches of the Hadley circulation at subtropical latitudes. The advection along the subtropical jets is closely related to the passage of waves and frontal zones along the subtropical jets. Such waves or fronts cause an acceleration of the flow and advection of polluted tropical air masses, while at the same time also cause transport of stratospheric air masses to the troposphere. However, the mode simulations show that stratospheric air masses remain at higher latitudes; generally they do not advance deep into the tropics. The discrepancy between measured and modeled $\mathrm{O}_{3}$ profiles close to India in 1998 is most likely related to the too high CTF along the subtropical jet. Other discrepancies in $\mathrm{O}_{3}$ profile shape between observations and model simulations are attributed to the model resolution.

Acknowledgements. The author thanks Russ Dickerson (University of Maryland, USA) and Kevin Rhoads for making the $1995 \mathrm{O}_{3}$ soundings available and Herman Smit from the Institute for Chemistry of the Polluted Atmosphere in Jülich for making the $1998 \mathrm{O}_{3}$ soundings available.

The former director of the Indian Meteorological Institute, Dr. Dev Sikka, is thanked for his insights, advice and suggestions.

\section{References}

Baray, J. L., Ancellet, G., Randriambelo, T., and Baldy, S.: Tropical cyclone Marlene and stratosphere-troposphere exchange, J. Geophys. Res., 104, 13 953-13 970, 1999.

Baray, J. L., Randriambelo, T., Baldy, S., and Ancellet, G.: Comment on "Tropospheric $\mathrm{O}_{3}$ distribution over the Indian Ocean during spring 1995 evaluated with a chemistry-climate model" by de Laat, A. T. J., et al., J. Geophys. Res., 106, 1365-1368, 2001.

Benkovitz, C. M., Scholtz, M. T., Pacyna, J., Tarrason, L., Dignon, J., Voldner, E. C., Spiro, P. A., Logan, J. A., and Graedel, T. E.: Global gridded inventories of anthropogenic emissions of sulfur and nitrogen, J. Geophys. Res., 101, 29239-29 254, 1996.

Chatfield, R. B. and Delaney, A. C.: Convection links biomass burning to increased tropical ozone: However, models will tend to overpredict $\mathrm{O}_{3}$, J. Geophys. Res., 95, 18 473-18 488, 1990.

Chatfield, R. B., Vastano, J. A., Singh, H. B., and Sachse, G.: A general model on how fire emissions and chemistry produce African/oceanic plumes $\left(\mathrm{O}_{3}, \mathrm{CO}, \mathrm{PAN}\right.$, and smoke $)$ in TRACE A, J. Geophys. Res., 101, 24 791-24 306, 1996.

Chen, C. T. and Roeckner, E.: Validation of the earth radiation budget as simulated by the Max Planck Institute for Meteorology general circulation model ECHAM4 using satellite observations of the Earth Radiation Budget Experiment, J. Geophys. Res., 101, 4269-4287, 1996.

Crutzen, P. J. and Andreae, M. O.: Biomass burning in the tropics: Impact on atmospheric chemistry and biogeochemical cycles, Science, 250, 1669-1678, 1990.

Crutzen, P J. and Carmichael, G. R.: Modeling the influence of fires on atmospheric chemistry, in: Fire in the Environment: The Ecological, Atmospheric, and Climatic Importance of Vegetation Fires, (Eds) Crutzen, P. J. and Goldammer, J. G., John Wiley, New York, pp. 89-106, 1993.

de Laat, A. T. J., Zachariasse, M., Roelofs, G. J., van Velthoven, P., Dickerson, R. R., Rhoads, K. P., Oltmans, S. J., and Lelieveld, J.: Tropospheric $\mathrm{O}_{3}$ distribution over the Indian Ocean during 
spring 1995 evaluated with a chemistry-climate model, J. Geophys. Res., 104, 13 881-13 893, 1999.

de Laat, A. T. J. and Lelieveld, J.: The diurnal $\mathrm{O}_{3}$ cycle in the tropical and subtropical marine boundary layer, J. Geophys. Res., 105, 11 547-11 559, 2000.

de Laat, A. T. J, Dickerson, R. R., Lelieveld, J., Lobert, J., and Roelofs, G. J.: Source analysis of Carbon $\mathrm{MoNO}_{\mathrm{X}}$ ide pollution during INDOEX, J. Geophys. Res., D22, 28 481-28 496, 2001.

de Laat, A. T. J. and Lelieveld, J.: Reply, J. Geophys. Res., 104, 1369-1371, 2001.

de Laat, A. T. J. and Lelieveld, J.: Interannual variability of the Indian winter monsoon circulation and consequences for pollution levels over the Indian Ocean, J. Geophys. Res., in press, 2002.

Folkins, I., Loewenstein, M., Podolske, J., Oltmans, S., and Proffitt, M.: A barrier to vertical mixing at $14 \mathrm{~km}$ in the tropics: Evidence from ozonesondes and aircraft measurements, J. Geophys. Res., 104, 22 095-22 102, 1999.

Galanter, M., Levy, II, H., and Carmichael, G. R.: Impacts of biomass burning on tropospheric $\mathrm{CO}, \mathrm{NO}_{\mathrm{X}}$ and $\mathrm{O}_{3}$, J. Geophys. Res., 105, 6633-6653, 2000.

Ganzeveld, L. N. and Lelieveld, J.: Dry deposition parameterization in a chemistry - general circulation model and its influence on the distribution of chemically reactive trace gases, J. Geophys. Res., 100, 20 999-21 012, 1995.

Ganzeveld, L. N., Lelieveld, J., and Roelofs, G. J.: A dry deposition parameterization for sulfur oxides in a chemistry and general circulation model, J. Geophys. Res., 103, 5679-5694, 1998.

Graedel, T. E. and Crutzen, P.: Atmospheric change: An earth perspective, AT\&T, pp. 446, Chapter 8, 1993.

Hao, W. M. and Liu, M. H.: Spatial and temporal distribution of tropical biomass burning, Global Biogeochem. Cycles, 8, 495503, 1994.

Haskins, R. D., Barnett, T. P., Tyree, M. M., and Roeckner, E.: Comparison of cloud fields from an atmospheric general circulation model, in situ and satellite measurements, J. Geophys. Res., 100, 1367-1378, 1995.

Hastenrath, S.: Climate and circulation in the tropics, Kluwer Academic Press, pp. 455, 1988.

Hertel, O., Berkowicz, R., Christensen, J., and Hov, O.: Test of two numerical schemes for use in atmospheric transport-chemistry models, Atmos. Env. 27A, 2591-2611, 1993.

Hoerling, M. P., Schaack, T. K., and Lenzen, A. J.: A global analysis of stratospheric tropospheric exchange during northern winter, Mon. Wea. Rev., 121, 162-172, 1993.

Jeuken, A. B. M., Siegmund, P.C., Heijboer, L. C., Feichter, J., and Bengtson, L.: On the potential of assimilating meteorological analysis in a climate model for the purpose of model validation, J. Geophys. Res., 101, 16 939-16950, 1996.

Kentarchos, A. S., Roelofs, G. J., and Lelieveld, J.: Model study of a stratospheric intrusion event at lower midlatitudes associated with the development of a cutoff low, J. Geophys. Res., 104, 1717-1727, 1999.

Kentarchos, A. S., Roelofs, G. J., and Lelieveld, J.: Simulation of extratropical synoptic scale stratosphere-troposphere exchange using a coupled chemistry-GCM: Sensitivity to horizontal resolution, J. Atmos. Sci, 57, 2824-2838, 2000.

Kentarchos, A. J., Roelofs, G. J., and Lelieveld, J.: Altitude distribution of tropospheric ozone over the northern hemisphere during 1996, simulated with a chemistry-GCM at 2 different hori- zontal resolutions, J. Geophys. Res., 106, 17 543-17 470, 2001.

Lal, S., Naja, M., and Jayaraman, A.: Ozone in the marine boundary layer over the tropical Indian Ocean, J. Geophys. Res., 55, 18 907-18917, 1998.

Lawrence, M. G. and Lal, S.: Elevated mixing ratios of surface ozone over the Arabian Sea, Geophys. Res. Lett., 28, 1487-1490, 2001.

Lelieveld, J. and van Dorland, R.: Ozone chemistry changes in the troposphere and consequent radiative forcing of climate, in: Atmospheric ozone as a climate gas, (Eds) Wang, W. C. and Isaksen, I. S. A., Springer-Verlag, Berlin, pp. 227-258, 1995.

Leon, J.-F., Chazette, P., Dulac, F., Pelon, J., Flamant, C., Bonazzola, M., Foret, G., Alfaro, S. C., Cachier, H., Cautenet, S., Hamonou, E., Gaudichet, A., Gomes, L., Rajot, J.-L., Lavenu, F., Inmdar, S. R., Sarode, P. R., and Kadadevarmath, J. S.: Largescale advection of continental aerosols during INDOEX, J. Geophys. Res, 106, 28 427-28 439, 2001.

Mandal, T. K., Kley, D., Smit, H. G. J., Srivastav, S. K., Peshin, S. K., and Mitra, A. P.: Vertical distribution of ozone over the Indian Ocean (15 N-15 S) during the First Field Phase INDOEX 1998, Current Science, 76, 938-943, 1999.

Peshin, S. K., Mandal, T. K., Smit, H. G. J., Srivastav, S. K., and Mitra, A. P.: Observations of vertical distribution of tropospheric ozone over the Indian Ocean and its comparison with continental profiles during INDOEX-FFP-1998 and IFP 1999, Current Science, 80, 197-208, 2001.

Pickering, K. E., Thompson, A. M., Scala, J. R., Tao, W.-K., Dickerson, R. R., and Simpson, J.: Free tropospheric ozone production following entrainment of urban plumes into deep convection, J. Geophys. Res., 97, 17 895-18 000, 1992.

Price, C. and Rind, D.: A simple lightning parameterization for calculating global lightning distributions, J. Geophys. Res., 97, 9919-9933, 1992

Randriambelo, T., Baray, J. L., Baldy, S., and Bremaud, P.: A Case study of extreme tropospheric ozone contamination in the tropics using in situ, satellite and meteorological data, Geophys. Res. Lett., 26, 1287-1290, 1999.

Rasch, P. J. and Williamson, D.: Computational aspects of moisture transport in global models of the atmosphere. Q. J. R. Meteorol. Soc., 116, 1071-1090, 1990.

Reiner, T., Sprung, D., Jost, D., Gabriel, R., Mayol-Bracero, O. L., Andreae, M. O., Campos, T. L., and Shetter, R. E.: Chemical characterization of pollution layers over the tropical Indian Ocean: Signatures of emissions from biomass and fossil fuel burning, J. Geophys. Res., 106, 28 497-28 510, 2001.

Rhoads, K. P., Kelley, P., Dickerson, R. R., Carsey, T. P., Farmer, M., Savoie, L., and Prospero, J. M.: Composition of the troposphere of the Indian Ocean during the monsoonal transition, J. Geophys. Res., 102, 18 981-18 995, 1997.

Roeckner, E., Arpe, K., Bengtsson, L., Christoph, M., Claussen, M., Dmenil, L., Esch, M., Giorgetta, M., Schlese, U., and Schulzweida, U.: The atmospheric general circulation model ECHAM-4: Model description and simulation of present-day climate, Rep. 218, Max-Planck-Institute for Meteorology, Hamburg, Germany, 1996.

Roelofs, G. J. and Lelieveld, J.: Distribution and budget of $\mathrm{O}_{3}$ in the troposphere calculated with a chemistry - general circulation model, J. Geophys. Res., 100, 20 983-20 998, 1995.

Roelofs, G. J. and Lelieveld, J.: Model study of the influence of 
cross-tropopause $\mathrm{O}_{3}$ transports on tropospheric $\mathrm{O}_{3}$ levels, Tellus, 49B, 38-55, 1997.

Roelofs, G. J., Lelieveld, J., Smit, H. G. J., and Kley, D.: Ozone production and transports in the tropical Atlantic region during the biomass burning season, J. Geophys. Res., 102, 10637-10651, 1997a.

Roelofs, G. J., Lelieveld, J., and van Dorland, R.: A threedimensional chemistry/general circulation model simulation of anthropogenically derived ozone in the troposphere and its radiative climate forcing, J. Geophys. Res., 102, 23 389-23 401, 1997b.

Roelofs, G. J. and Lelieveld, J.: Tropospheric ozone simulated with a chemistry-general circulation model: Influence of higher hydrocarbon chemistry, J. Geophys. Res., 105, 22 697-22 712, 2000.

Siegmund, P. C., van Velthoven, P. F. J., and Kelder, H.: Crosstropopause transport in the extratroipcal northern winter hemisphere, diagnosed from high-resolution ECMWF data, W. J. R. Meteorol. Soc., 122, 1921-1941, 1996.

Smit, H. G. J., Sträter, W., Kley, D., and Profitt, M. H.: The evaluation of ECC-ozone sondes under quasi flight conditions in the environmental simulation chamber at Jülich, in: Proceedings of Eurotrac Symposium 1994, (Eds) Borell, P. M., et al., SPB Acad., The Hague, the Netherlands, pp. 349-353, 1994.
Smit, H. G. J., Gilge, S., and Kley, D.: JOSIE: The 1996 WMO international intercomparison of ozone sondes under quasi flight conditions in the environmental simulation chamber at Jülich, Tech Doc. 296, World Meteorol. Org., Geneva, 1998.

Thompson, A. M., Pickering, K. E., McNamara, D. P., Schoeberl, M. R., Hudson, R. D., Kim, J. H., Browell, E. V., Kirchhoff, V. W. J. H., and Nganga, D.: Where did tropospheric zone over southern Africa and the tropical Atlantic come from in October 1992? Insights from TOMS, GTE TRACE A and SAFARI 1992, J. Geophys. Res., 101, 24 251-24 278, 1996.

Tiedtke, M.: A comprehensive mass flux scheme for cumulus parameterization in large-scale models, Mon. Wea. Rev., 117, 1779-1800, 1989.

Yienger, J. J. and Levy, II, H.: Empirical model of global soilbiogenic $\mathrm{NO}_{\mathrm{X}}$ emissions, J. Geophys. Res., 100, 11 447-11 464, 1995.

Zachariasse, M., van Velthoven, O. F. J., Smit, H. G. J., Lelieveld, J., Mandal, T. K., and Kelder, H.: Influence of stratospheretroposphere exchange on tropospheric ozone over the tropical Indian Ocean during the winter monsoon, J. Geophys. Res., 105, 15 403-15 416, 2000.

Zachariasse, M., Smit, H. G. J., van Velthoven, P. F. J., and Kelder, H.: Cross-troposphere and interhemispheric transports into the tropical free troposphere over the Indian Ocean, J. Geophys. Res., 106, 28 441-28 453, 2001. 